\title{
GEODYNAMIC ACTIVITY OF MODERN STRUCTURES AND TECTONIC STRESS FIELDS IN NORTHEAST ASIA
}

\author{
L. P. Imaeva1, 2, G. S. Gusev³, V. S. Imaev1, 2, S. V. Ashurkov1, 2, \\ V. I. Melnikova', ${ }^{1}$, A. I. Seredkina1, 2 \\ 1 Institute of the Earth's Crust, Siberian Branch of RAS, Irkutsk, Russia \\ ${ }^{2}$ Institute of Diamond and Precious Metals Geology, Siberian Branch of RAS, Yakutsk, Russia \\ ${ }^{3}$ Institute of Mineralogy, Geochemistry and Crystal Chemistry of Rare Elements of RAS, Moscow, Russia
}

\begin{abstract}
Based on the analysis of changes in the stress-strain state of the crust at the boundary of the Eurasian and North American tectonic plates, we develop a dynamic model of the main seismogenerating structures in Northeast Asia. We have established a regularity in changes of geodynamic regimes within the interplate boundary between the Kolyma-Chukotka crustal plate and the Eurasian, North American and Pacific tectonic plates: spreading in the Gakkel Ridge area; rifting in the Laptev Sea shelf; a mixture of tectonic stress types in the Kharaulakh segment; transpression in the Chersky seismotectonic zone, in the segment from the Komandor to the Aleutian Islands, and in the Koryak segment; and crustal stretching in the Chukotka segment.
\end{abstract}

Key words: regional segments; active faults; parageneses of active structures; paleoseismogenic structures; Late Cenozoic deformation; earthquake focal mechanism; seismotectonic deformation; GPS data; crustal stress-strain state

\section{RESEARCH ARTICLE}

For citation: Imaeva L.P., Gusev G.S., Imaev V.S., Ashurkov S.V., Melnikova V.I., Seredkina A.I., 2017. Geodynamic activity of modern structures and tectonic stress fields in Northeast Asia. Geodynamics \& Tectonophysics 8 (4), 737-768. doi:10.5800/GT-2017-8-4-0315.

Для цитирования: Имаева Л.П., Гусев Г.С., Имаев В.С., Ашурков С.В., Мельникова В.И., Середкина А.И. Геодинамическая активность новейших структур и поля тектонических напряжений северо-востока Азии // Геодинамика и тектонофизика. 2017. C. 737-768. doi:10.5800/GT-2017-8-4-0315. 


\title{
ГЕОДИНАМИЧЕСКАЯ АКТИВНОСТЬ НОВЕЙШИХ СТРУКТУР И ПОЛЯ ТЕКТОНИЧЕСКИХ НАПРЯЖЕНИЙ СЕВЕРО-ВОСТОКА АЗИИ
}

\author{
Л.П. Имаева ${ }^{1,2}$, Г.С. Гусев ${ }^{3}$, В.С. Имаев ${ }^{1,2}$, С.В. Ашурков ${ }^{1,2}$, \\ В.И. Мельникова ${ }^{1,2}$, А.И. Середкина ${ }^{1,2}$ \\ ${ }^{1}$ Институт земной коры СО РАН, Иркутск, Россия \\ ${ }^{2}$ Институт геологии алмаза и благородных металлов СО РАН, Якутск, Россия \\ ${ }^{3}$ Институт минералогии, геохимии и кристаллохимии редких элементов РАН, Москва, Россия
}

\begin{abstract}
Аннотация: Анализ изменений напряженно-деформированного состояния земной коры, проведенный вдоль границы Евразийской и Североамериканской литосферных плит, позволил обосновать динамическую модель главных сейсмогенерирующих структур территории северо-востока Азии. В пределах единой межплитной границы, отделяющей Колымо-Чукотскую коровую плиту от Евразийской, Североамериканской и Тихоокеанской литосферных плит, наблюдается закономерная смена геодинамических режимов: спрединг хребта Гаккеля; рифтогенез на шельфе моря Лаптевых; смешанное поле тектонических напряжений в Хараулахском сегменте; транспрессия в сейсмотектонической зоне Черского, на участке от Командорских до Алеутских островов и в Корякском сегменте; растяжение в Чукотском сегменте.
\end{abstract}

Ключевые слова: региональные сегменты; активные разломы; парагенезисы активных структур; палеосейсмогенные структуры; позднекайнозойские деформации; механизм землетрясения; сейсмотектонические деформации; GPS-данные; режимы напряженно-деформированного состояния земной коры

\section{1. ВВЕДЕНИЕ}

Данная статья является обзорной и отражает результаты комплексных сейсмотектонических исследований, проведенных в рамках проекта РНФ «Сейсмогеодинамический анализ и сейсмическое районирование восточного сегмента прибрежношельфовой области Российской Арктики». Она включает новые исследования, а также краткие сейсмотектонические характеристики Арктического сектора из ранее опубликованных работ [Imaeva et al., 2015a, 2016a, 2016b, 2016c; Seredkina, Kozmin, 2017]. Описание сегментов в данной последовательности необходимо для полной характеристики напряженно-деформированного состояния земной коры вдоль структурного ограничения КолымоЧукотской коровой плиты.

Целью исследований является определение типов сейсмотектонической деструкции земной коры в очаговых зонах сильных землетрясений, расположенных на границах литосферных и коровых плит территории северо-востока Азии (рис. 1). Зона взаимодействия данных плит подразделяется на сегменты с характерным для каждого из них набором активных структур и определенным типом напряженно-деформированного состояния земной коры. Нами рассматриваются сегменты АрктикоАзиатского и Охотско-Чукотского сейсмических поясов, ограничивающие по периметру КолымоЧукотскую коровую плиту, которая как самостоятельный тектонический таксон впервые выделена Г.С. Гусевым с соавторами [Gusev et al., 2016].

Сегментами Арктико-Азиатского сейсмического пояса являются спрединговый хребет Гаккеля, рифтовые впадины шельфа моря Лаптевых и сейсмотектоническая зона Черского. В Охотско-Чукотском сейсмическом поясе нами рассматриваются активные структуры Корякского и Чукотского сегментов. По результатам полевых исследований и литературным данным для каждого из них проведен анализ структурно-тектонического положения, параметров глубинного строения и систем активных структурообразующих разломов. На основе механизмов очагов землетрясений рассчитаны средние тензоры сейсмотектонических деформаций, по данным GPS-измерений определены скорости деформаций. Проведенный алгоритм исследований позволил выявить зональность напряженно-деформированного состояния земной коры и создать региональную структурно-динамическую модель главных сейсмогенерирующих структур территории северо-востока Азии. 
$80^{\circ}$

$60^{\circ}$
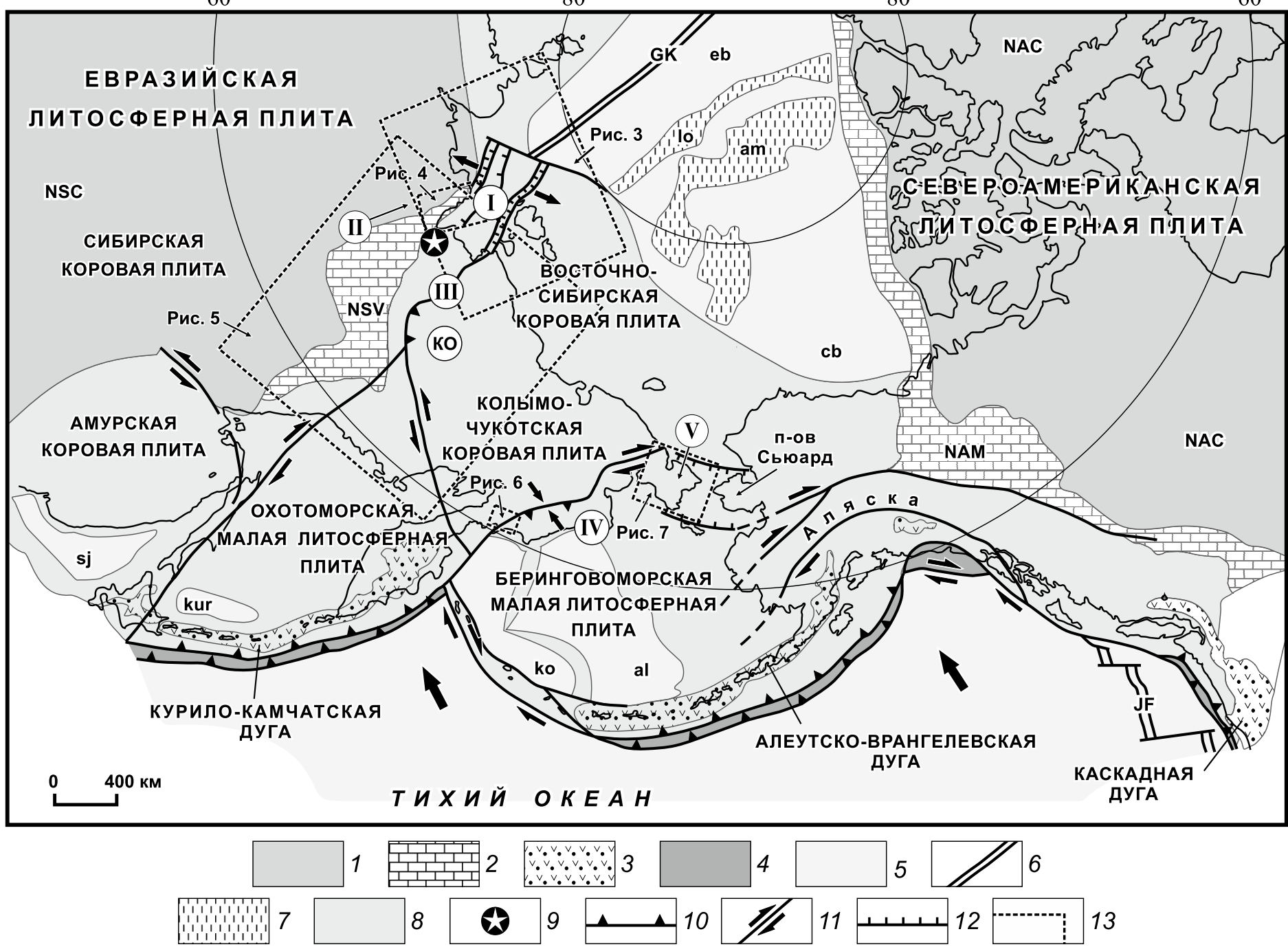

Рис. 1. Современная геодинамика и кинематика плит северо-восточного сектора Арктики (по [Nokleberg et al., 2000; Parfenov et al., 2001] с изменениями и дополнениями).

1 - кратоны: NSC - Североазиатский, NAC - Североамериканский; 2 - опущенные окраины кратонов (ископаемые пассивные континентальные окраины): NAM - Североамериканского, NSV - Североазиатского (Верхоянский складчато-надвиговый пояс); 3 - окраинно-континентальные и островные магматические дуги; 4 - аккреционные клинья; 5 - океаны и бассейны с океанической корой: eb - Евразийский бассейн, cb - Канадский бассейн, al - Алеутский бассейн, ko - Командорский бассейн, sj - Японское море, kur - Южно-Курильская впадина; 6 - срединно-океанические хребты: GK - хребет Гаккеля, JF - хребет Хуан де Фука; 7 внутриокеанические поднятия: lo - хребет Ломоносова, аm - хребты Альфа и Менделеева; 8 - коллаж аккретированных террейнов; 9 - местоположение полюса вращения Евразийской и Североамериканской плит; 10 - надвиги; 11 - границы плит с разным направлением относительных перемещений; 12 - сбросы; 13 - границы и расположение рисунков. Сегменты Арктико-Азиатского сейсмического пояса: I - Лаптевоморский, II - Хараулахский, III - сейсмотектоническая зона Черского. Сегменты Охотско-Чукотского сейсмического пояса: IV - Корякский, V - Чукотский. КО - Колымо-Омолонский блок.

Fig. 1. Recent geodynamics and kinematics of plates in the Northeast Arctic (modified from [Nokleberg et al., 2000; Parfenov et al., 2001]).

1 - cratons: NSC - North Asian, NAC - North American; 2 - subsided margins of cratons (fossil passive continental margins): NAM - North American craton, NSV - North Asian craton (Verkhoyansk fold-thrust belt); 3 - marginal continental and island magmatic arcs; 4 - accretionary wedges; 5 - oceans and basins with oceanic crust: eb - Eurasian basin, cb - Canadian basin, al - Aleutian basin, ko - Commander basin, sj - Sea of Japan, kur - South Kuril basin; 6 - mid-oceanic ridges: GK - Gakkel Ridge, JF - Ridge Juan de Fuca; 7 - intra-oceanic uplifts: lo - Lomonosov Ridge, am - Alpha and Mendeleev ridges; 8 - collage of accreted terranes; 9 - location of the pole of rotation of the Eurasian and North American plates; 10 - thrusts; 11 - boundaries of plates with different directions of relative displacements; 12 - normal faults; 13 - boundaries and location of the figures. Segments of the Arctic-Asian seismic belt: I - Laptev, II - Kharaulakh, III - Chersky seismotectonic zone. Segments of the Okhotsk-Chukotka seismic belt: IV - Koryak, V - Chukotka. KO - Kolyma-Omolon block. 


\section{2. МЕТОДЫ ИССЛЕДОВАНИЙ}

В рамках многолетних исследований авторским коллективом проекта был разработан и апробирован комплексный подход к решению задач сейсмотектонического анализа в зонах сейсмогенерирующих структур с различным типом геодинамического режима. Он базируется на структурногеометрическом изучении деформаций в зонах динамического влияния активных разломов с определенным типом напряженного состояния земной коры. Составными частями этого метода являются проведение детальных работ по установлению структурных парагенезисов активных разломов и типов позднекайнозойских складчатых и разрывных деформаций, изучение структурно-тектонической позиции основных эпицентральных полей, крупномасштабные тектонофизические, палеосейсмологические, морфотектонические и неотектонические исследования, морфометрические построения, дешифрирование дистанционных материалов и снимков лазерного сканирования [Imaev et al., 2000; Imaeva et al., 2011, 2015a, 2015b, 2016b].

Определение степени геодинамической активности неотектонических структур. По степени активности и направленности геодинамических процессов были разработаны региональные принципы классификации неотектонических структур северо-восточного сектора прибрежно-шельфовой области Российской Арктики с обоснованием их дифференциации на классы [Gusev et al., 2016]. Новейший геодинамический площадной таксон территориального ранга (домен) рассматривается как пространственно локализованный целостный объект с многофакторным взаимодействием его основных компонентов в разрезе земной коры. Здесь мы используем термины «домен» и «новейшая структура» как синонимы, а термин «сегмент» относим к ряду доменов (новейших структур), которые в своем развитии подчиняются единым геодинамическим условиям.

Классификация доменов представляет собой многоуровневую систему, состоящую из девяти классов активности современных геодинамических процессов формирования неотектонических структур. Каждый класс активности определяют свойственный ему набор и оптимальное количество признаков: тектоническая (геодинамическая) обстановка, вещественный состав, геофизические параметры (величина теплового потока, аномалии поля силы тяжести, мощность земной коры), характеристики рельефа (высота, его контрастность, скорость вертикального и горизонтального перемещения земной поверхности). Дополнительно рассматривались унаследованность структур от условий формирования в предшествующие этапы развития домена, а также деформационные признаки и GPS-данные. Определение геодинамической активности неотектонических структур и установление конкретного класса осуществляются путем интерпретации как первичных, так и дополнительных признаков.

По степени активности новейших тектонических движений классы доменов объединяются в три группы: низкой активности (классы 1-2), умеренной активности (классы 3-5), высокой активности (классы 6-9). Характеристики классов отображают зональность активности геодинамических процессов и совместно с активными разломами составляют главное содержание «Схемы геодинамической активности неотектонических структур и сейсмотектонических деформаций северо-восточного сектора Арктики» (рис. 2). На схему дополнительно нанесены направления главных осей сейсмотектонических деформаций, рассчитанные по сейсмологическим данным.

Сейсмотектонические деформации (СТД) по сейсмологическим данным. Реконструкция напряженно-деформированного состояния земной коры в сейсмически активных регионах Земли является неотъемлемой частью изучения природы сейсмического процесса и развития геодинамических моделей. С этой целью широко используются инверсионные схемы оценки как тензора напряжений [Angelier, 1979; Gephart, Forsyth, 1984; Gushchenko, 1979; Heidbach et al., 2010], так и тензора сейсмотектонических деформаций [Kostrov, 1975; Riznichenko, 1985; Yunga, 1990, 1997; Rebetsky, 2007; Rebetsky et al., 2012]. Входными данными при этом являются материалы геолого-структурных исследований, механизмы очагов землетрясений и другие индикаторы современных напряжений и деформаций. Основное допущение - их однородность в пространстве и времени.

В данной работе реконструкция СТД осуществлялась в различных сейсмоактивных объемах земной коры по периметру структурного ограничения Колымо-Чукотской коровой плиты по методу С.Л. Юнги [Yunga, 1990]. Параметры СТД оценивались средним тензором деформаций, который вычислялся как произведение тензора среднего механизма на сумму сейсмических моментов землетрясений, нормированную по объему и модулю сдвига. В предположении подобия СТД на разных масштабных уровнях в расчет вводилась весовая функция, полученная по среднемировым данным [Yunga, 1997]. Тензор среднего механизма характеризуется тремя собственными значениями и положением соответствующих главных осей деформаций: Т - удлинения (растяжения), В - промежуточной, Р - укорочения (сжатия). Данные оси, при 
условии рассмотрения обобщенно-плоской части деформации, используются для построения карт ориентировок главных деформаций [Yunga, 1997]. Еще одним важным параметром при расчете СТД является интенсивность среднего тензора $(0<\chi<1)$, которая отражает степень соответствия результирующей матрицы и матрицы индивидуального механизма. Крайние точки показывают отсутствие закономерности в ориентации механизмов $(\chi=0)$ и их полную тождественность $(\chi=1)$.

Основой для расчета и анализа параметров СТД служили решения механизмов очагов 248 землетрясений $(M \geq 3.5)$ за период 1927-2016 гг., заимствованные из международных сейсмологических центров [International Seismological Centre, 2017; Department..., 2017; Global Centroid Moment Tensor Project..., 2017; National Earthquake Information Center..., 2017] и литературных источников [Balakina et al., 1972; Fujita et al., 2009]. Большая часть решений была получена путем расчета тензора сейсмического момента, остальные - по знакам первых вступлений объемных сейсмических волн. Выбор сейсмоактивных объемов земной коры (при условии их однородного деформирования) определялся площадным распределением эпицентров землетрясений и глубиной 20 км. Таким образом, из общего числа сейсмических событий было выделено 23 группы пространственно близких землетрясений (табл. 1). Согласно методике [Yunga, 1990; Sycheva et al., 2009], осреднение исходных данных в каждом объеме осуществлялось по методу «узловых точек», при этом вид напряженно-деформированного состояния геологической среды, согласно классификации С.Л. Юнги [Yunga, 1997], определялся горизонтальной проекцией главных осей деформаций. Параметры СТД, рассчитанные по сейсмологическим данным, представлены на рисунке 2 и в таблице 1 . Ниже рассмотрим тектоническое положение новейших структур, параметры глубинного строения, системы активных разломов, а также поля тектонических напряжений, установленные на основе тектонофизического анализа разрывных и складчатых позднекайнозойских деформаций.

\section{3. АКТИВНЫЕ СЕГМЕНТЫ}

Лаптевоморский сегмент в сейсмотектоническом плане по данным морских геофизических исследований выражен системой грабенов и прогибов северо-западного простирания [Avetisov, 1996; Bogdanov, 2001; Drachev, 2002; Anokhin et al., 2003]. Пространственное распределение эпицентров землетрясений от хребта Гаккеля к шельфу моря Лаптевых свидетельствует о смене линейной деструк- ции земной коры, характерной для спрединговой зоны, на диффузную (рис. 2, 3). Вдоль западной и восточной границ шельфа моря Лаптевых выявлены две линейные зоны слабых землетрясений. Первая фиксируется через дельту р. Лены вдоль Оленекского сектора побережья моря Лаптевых к полуострову Таймыр, а вторая следится из акватории Восточно-Сибирского моря между островами Котельный и Новая Сибирь.

На основе анализа фокальных механизмов местных землетрясений, произошедших на юго-восточном окончании спрединговой зоны хребта Гаккеля, континентальном склоне и в рифтовых впадинах шельфа моря Лаптевых [Yunga, 1990], проводился расчет параметров СТД (рис. 2, 3). Использовались данные о тензоре сейсмического момента и центроиде событий из каталога Global CMT и «Бюллетеня международного сейсмологического центра (ISC)»[Fujita, Koz'min, 1994]. Полученные результаты однозначно свидетельствуют о том, что в указанных областях Арктического сектора доминирует сейсмотектонический режим растяжения (группы 1-8 в табл. 1, рис. 2, 3). Главные оси напряжений растяжения направлены вкрест простирания основных структурных элементов и при пологих углах погружения имеют северо-восток юго-западное направление. В пределах континентальной границы Лаптевоморской рифтовой системы и Сибирской платформы, выраженной Оленекским сектором Верхоянского складчато-надвигового пояса, также действует преимущественно режим растяжения земной коры, но с небольшой сдвиговой компонентой.

Очевидно, что большинство местных землетрясений характеризуются сбросовыми смещениями в очагах (рис. 2, 3). Однако исключение составляют фокальные механизмы Таймырских землетрясений 1990 и 2015 гг. с $M_{\mathrm{w}}=4.3$, которые имеют максимальную для рассматриваемого района магнитуду и интенсивность по шкале MSK-64 [Seredkina, Kozmin, 2017]. В результате проведенного исследования было установлено, что в очагах этих событий реализовались пологая и субвертикальная плоскости разрывов северо-западного (в северных румбах) (1990 г.), северо-восточного (2015 г.) и субмеридионального (в обоих случаях) простираний со взбросо-сдиговой и взбросовой подвижками. При этом простирание возможных плоскостей разрыва близко к простиранию фиксируемых в рельефе молодых разломов.

Выявленный режим сжатия, существенно отличающийся от механизмов всех сейсмических событий, произошедших вдоль побережья Оленекского и Анабарского заливов моря Лаптевых, согласуется с материалами геолого-структурных изысканий [Geological Map..., 1986], а также оценками скорости 


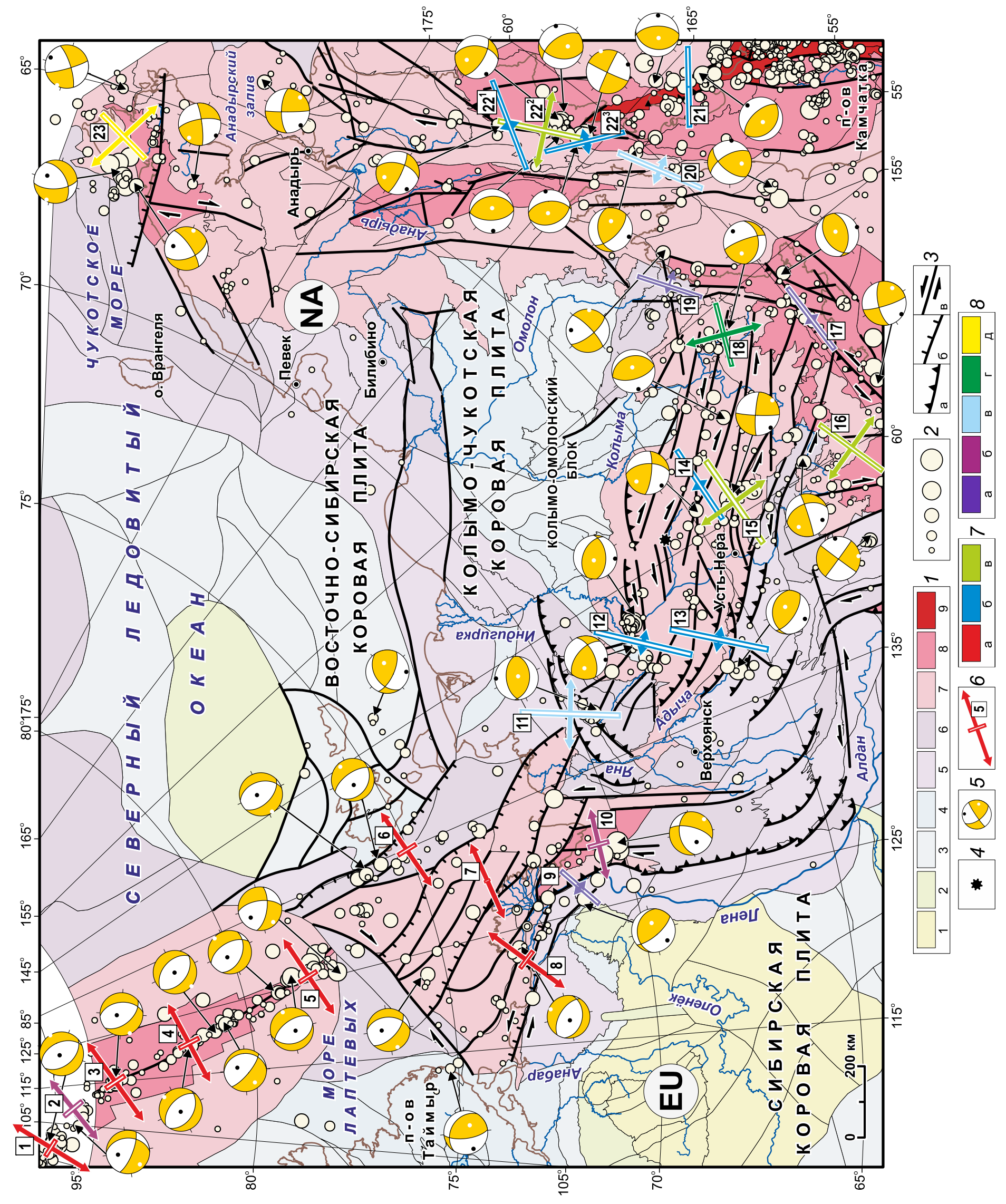


Рис. 2. Схема геодинамической активности неотектонических структур и сейсмотектонических деформаций северо-восточного сектора Арктики.

1 - классы геодинамической активности: 1-2 - низкой, 3-5 - умеренной, 6-9 - высокой; 2 - эпицентры землетрясений с магнитудой $(M)$, соответственно: $\leq 4.0,4.1-5.0,5.1-6.0,6.1-7.0, \geq 7.0$ (сейсмичность представлена по данным ЯФ ГС СО РАН и ГС РАН); 3 активные разломы и их кинематика: $a$ - надвиги, $\sigma$ - сбросы, в - сдвиги; 4 - вулкан Балаган-Тас; 5 - фокальные механизмы землетрясений с указанием даты их возникновения и магнитуды (нижняя полусфера, выходы осей главных напряжений сжатия и растяжения обозначены черными и белыми точками); 6 - горизонтальная проекция главных осей деформаций (растяжения, сжатия) с указанием номера области расчета СТД (табл. 1). Режимы СТД: 7 - основные (а - растяжение, б - сжатие, в - сдвиг), 8 переходные ( $a$ - от вертикального режима к сжатию, б - от вертикального режима к растяжению, в - от сдвига к сжатию, 2 - косой сдвиг, $\partial-$ от сдвига к растяжению).

Fig. 2. Geodynamic activity of neotectonic structures and seismotectonic deformations of the Northeast Arctic.

1 - classes of geodynamic activity: 1-2 - low, 3-5 - medium, 6-9 - high; 2 - earthquake epicenters grouped by magnitude: $\leq 4.0$, 4.1-5.0, 5.1-6.0, 6.1-7.0, $\geq 7.0$ (data published by the Geophysical Survey of the Russian Academy of Sciences (GS RAS) and its Yakutian branch); 3 - active faults and their kinematics: a - thrusts, 6 - normal faults, B - strike-slip faults; 4 - Balagan-Tas volcano; 5 - focal mechanisms, dates, and magnitudes of earthquakes (lower hemisphere; the axes of the main compressional and extensional stresses are marked by black and white dots); 6 - horizontal projections of the principal strain axes (extension, compression) and numbers of the areas for STD calculations (see Table 1). STD regimes: 7 - main (a - extension, 6 - compression, в - shear), 8 - transitional (a - from vertical strain to compression, $\sigma$ - from vertical strain to extension, B - from slip to compression, $\Gamma$ - oblique slip, $д$ - from slip to extension).

видимого поднятия побережья моря Лаптевых, установленными в результате длительных наблюдений за уровнем Мирового океана [Stovas, 1965].

На восточной границе Лаптевоморского блока в зоне контакта с Восточно-Сибирской коровой плитой в 1973 г. зарегистрировано землетрясение со взбросовыми подвижками в его очаге (рис. 2, 3). Таким образом, результаты сейсмологических исследований свидетельствуют о режиме сжатия на западной и восточной границах Лаптевоморской коровой плиты. Это можно интерпретировать как реакцию на рифтинг, господствующий на шельфе моря Лаптевых.

Хараулахский сегмент в тектоническом плане выражен северной зоной Западно-Верхоянского сектора, испытавшего главную фазу складчатости в раннем мелу [Khain, 1973; Parfenov, 1984]. Ее заложение в рифее на переработанном крае Сибирской платформы и длительная эволюция в качестве обширной пассивной континентальной окраины, аккумулировавшей мощную многокилометровую призму осадков, наложили определенный отпечаток на структуру и характер наблюдаемых дислокаций.

События кайнозойской истории связаны с взаимодействием Североамериканской и Евразийской литосферных плит на северо-востоке Азии. Важнейшим следствием этого взаимодействия явился рифтогенез на продолжении спредингового хребта Гаккеля, приведший к частичной деструкции континентальной коры на обширных площадях, в том числе и в Северном Верхоянье [Grachev et al., 1973; Savostin, Karasik, 1981; Grachev, 1982]. Структурнотектоническими исследованиями установлено чередование эпох сжатия и растяжения, что можно объяснить неоднократным изменением положения полюса вращения Североамериканской и Евразийской плит [Zonenshain et al., 1990; Fujita, Koz'min, 1994; Imaev et al., 2000; Parfenov et al., 2001].

В Хараулахском сегменте кайнозойский мегакомплекс представлен в основном палеоцен-эоценовыми континентальными отложениями, залегающими с резким угловым несогласием на различных горизонтах дислоцированного докембрийскомезозойского мегакомплекса [Grachev et al., 1973]. Они выполняют ряд субдолготно ориентированных впадин, наиболее известными из которых являются Кенгдейская, Кунгинская, Няйбинская и другие (рис. 4). Их заложение в палеогене обусловлено наиболее ранней фазой рифтогенеза в области континентального продолжения спредингового хребта Гаккеля. В некоторых местах палеогеновые осадки смяты в складки и разбиты надвигами и взбросами. Все эти факты указывают на проявление в кайнозое фазы сжатия.

Результаты специальных структурных исследований позволяют говорить о субширотной ориентировке оси сжатия, а рассмотрение данных по кайнозойским разрезам Хараулахского сегмента и сопредельных территорий приводит к выводу о среднемиоценовом возрасте деформаций сжатия [Drachev, 2002]. Следующим эпизодом кайнозойской истории района была фаза растяжения в плиоцен-четвертичное время. Молодые сбросы, смещающие неогеновую кору выветривания, протягиваются вдоль побережья залива Буор-Хая (рис. 4). Ось растяжения была ориентирована в субширотном или северо-восточном направлении.

По совокупности геолого-геофизической информации в Хараулахском сегменте установлены 
Т а б л и ц а 1. Режимы сейсмотектонических деформаций (СТД) северо-восточного сектора Арктики

$\mathrm{T}$ a b l e 1. Regimes of seismotectonic deformation (STD) in the Northeast Arctic

\begin{tabular}{|c|c|c|c|c|c|c|c|}
\hline & \multicolumn{2}{|c|}{ Координаты узловых точек } & \multirow[t]{2}{*}{ Области расчета СТД } & \multirow[t]{2}{*}{$\mathrm{N}$} & \multirow[t]{2}{*}{$\chi$} & \multirow[t]{2}{*}{$\mathrm{R}$, км } & \multirow[t]{2}{*}{ Режим СТД } \\
\hline & $\varphi^{\circ}$, с.ш. & $\lambda^{\circ}$, в.д. & & & & & \\
\hline 1 & 85.00 & 97.00 & хребет Гаккеля & 10 & 0.90 & 50 & $\mathrm{~N}$ \\
\hline 3 & 83.40 & 115.00 & хребет Гаккеля & 7 & 0.89 & 40 & $\mathrm{~N}$ \\
\hline 4 & 81.50 & 120.00 & хребет Гаккеля & 12 & 0.94 & 150 & $\mathrm{~N}$ \\
\hline 5 & 78.47 & 126.00 & хребет Гаккеля & 10 & 0.73 & 100 & $\mathrm{~N}$ \\
\hline 7 & 73.50 & 130.00 & Усть-Янская & 4 & 0.83 & 200 & $\mathrm{~N}$ \\
\hline 8 & 72.90 & 122.80 & Оленекская & 3 & 0.79 & 130 & $\mathrm{~N}$ \\
\hline \multicolumn{8}{|c|}{ Хараулахский сегмент } \\
\hline 9 & 71.40 & 127.20 & Чекуровская & 5 & 0.51 & 50 & TV \\
\hline 10 & 70.50 & 130.00 & Хараулахская & 4 & 0.74 & 40 & NV \\
\hline \multicolumn{8}{|c|}{ Яно-Индигирский сегмент зоны Черского } \\
\hline 14 & 64.50 & 147.50 & Улахан & 5 & 0.74 & 150 & $\mathrm{~T}$ \\
\hline 15 & 63.80 & 145.80 & Чай-Юреинская & 5 & 0.64 & 80 & $\mathrm{~S}$ \\
\hline 16 & 61.00 & 145.00 & Охотско-Кухтуйская & 4 & 0.83 & 150 & S \\
\hline 17 & 59.80 & 150.15 & Челомджа-Ямская & 3 & 0.71 & 200 & TV \\
\hline 18 & 62.00 & 153.55 & Купкинская & 3 & 0.82 & 50 & 0 \\
\hline 19 & 62.40 & 156.80 & Омсукчанская & 6 & 0.54 & 80 & TV \\
\hline \multicolumn{8}{|c|}{ Камчатский сегмент } \\
\hline 20 & 60.05 & 161.00 & Гежигинско-Пенжинская & 3 & 0.74 & 100 & TS \\
\hline 21 & 58.5 & 164.00 & Карагинская & 4 & 0.91 & 100 & $\mathrm{~T}$ \\
\hline \multicolumn{8}{|c|}{ Корякский сегмент } \\
\hline $22^{1}$ & 61.80 & 169.50 & Олюторская ${ }^{1}$ & 19 & 0.86 & 150 & $\mathrm{~T}$ \\
\hline
\end{tabular}

П р и м е ч а н и е. $N$ - количество фокальных механизмов, используемых при расчете Стд; $\chi-$ коэффициент интенсивности среднего механизма, отражающий степень соответствия результирующего тензора и тензора индивидуального механизма (пределы изменения: $0 \leq \chi \leq 1) ; R$ - радиус области расчета СТД. Режимы СТД: N - растяжение, T - сжатие, $\mathrm{S}-$ сдвиг, $\mathrm{O}$ - косой сдвиг, NV переход от вертикального режима к растяжению, TV - переход от вертикального режима к сжатию, TS - переход от сдвига к сжатию, NS - переход от сдвига к растяжению.

$\mathrm{N}$ o t e. $N$ - number of focal mechanisms used in the STD calculations; $\chi$ - intensity factor of the average mechanism, which reflects the degree of conformity of the resultant tensor and individual tensor $(0 \leq \chi \leq 1) ; R, \mathrm{~km}-$ radius of the STD calculation window. STD regimes: $\mathrm{N}-$ extension, $\mathrm{T}$ - compression, $\mathrm{S}$ - strike-slip, $\mathrm{O}$ - oblique slip, $\mathrm{NV}$ - transition from the vertical strain to extension, TV - transition from the vertical strain to compression, TS - transition from slip to compression, NS - transition from slip to extension.

системы региональных разломов, в зонах динамического влияния которых выявлены разномасштабные сейсмогенные структуры, соответствующие сейсмическим событиям с магнитудой от 6.0 до 7.0. Наиболее активна Хараулахская зона долготных сбросо-сдвиговых нарушений, расположенных кулисообразно друг к другу. Активность Хараулахских разломов подчеркивается яркой выраженностью на аэрофотоснимках, приуроченностью к ним значительного числа сейсмопроявлений и дислокаций в виде ложбин, рвов, оползней и обва- лов. Данная система обладает самым высоким сейсмическим потенциалом. На ее южном окончании в 1927-1928 гг. произошло пять сильных Булунских землетрясений с $M=5.8-7.0$, в эпицентральной зоне которых выявлено более 20 сейсмодислокаций гравитационного и тектонического генезиса (рис. 4).

Выполненные структурно-динамические исследования указывают на существование в Хараулахском сегменте областей с разным типом напряженного состояния земной коры [Imaev et al., 2000; Imaeva et al., 2016c]. Это подтверждается данными 


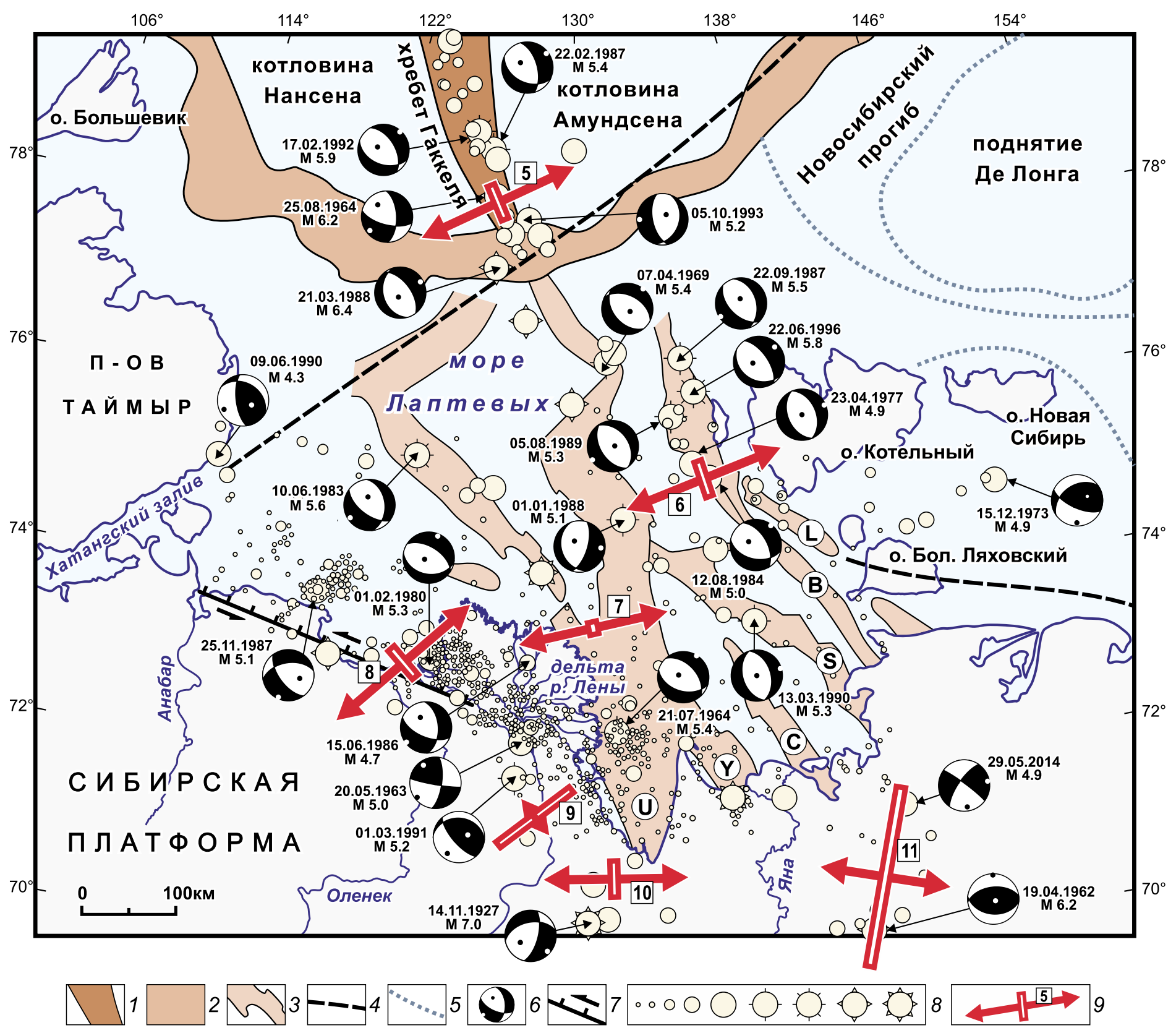

Рис. 3. Схема сейсмотектоники Лаптевоморского сегмента (по [Parfenov, Kuzmin, 2001], с изменениями и дополнениями).

1 - спрединговый хребет Гаккеля; 2 - континентальный склон; 3 - грабены дна моря Лаптевых (буквы в кружках): L - Ляховский, В - Бельковско-Святоносский, S - Широстонский, С - Чондонский, Y - Усть-Янский, U - Усть-Ленский; 4 - предполагаемые трассы активных разломов; 5 - границы крупных прогибов и поднятий; 6 - фокальные механизмы землетрясений с указанием даты их возникновения и магнитуды (нижняя полусфера, выходы осей главных напряжений сжатия и растяжения обозначены черными и белыми точками); 7 - Лено-Анабарский структурный шов; 8 - эпицентры землетрясений, соответственно с магнитудой $(M): 3.0,3.5,4.0,4.5,5.0,5.5,6.0,6.5,7.0$ (данные ЯФ ГС СО РАН и ГС РАН); 9 - горизонтальная проекция главных осей деформаций (растяжения, сжатия) с указанием номера области расчета СТД (табл. 1).

Fig. 3. Seismotectonics of the Laptev Sea segment (modified from [Parfenov, Kuzmin, 2001]).

1 - spreading Gakkel ridge; 2 - continental slope; 3 - grabens at the bottom of the Laptev Sea (letters in circles): L - Lyakhov, B - Belkovsky-Svyatoy Nos, S - Shirostonsky, C - Chondonsky, Y - Ust-Yana, U - Ust-Lena; 4 - assumed active faults; 5 - boundaries of large troughs and uplifts; 6 - focal mechanisms, dates, and magnitudes of earthquakes (lower hemisphere; the axes of the principal compressional and extensional stresses are marked by black and white dots); 7 - Lena-Anabar structural suture; 8 - earthquake epicenters grouped by magnitude: 3.0, 3.5, 4.0, 4.5, 5.0, 5.5, 6.0, 6.5, 7.0 (data published by the Geophysical Survey of the Russian Academy of Sciences (GS RAS) and its Yakutian branch); 9 - horizontal projections of the principal strain axes (extension, compression) and numbers of the areas for STD calculations (see Table 1). 


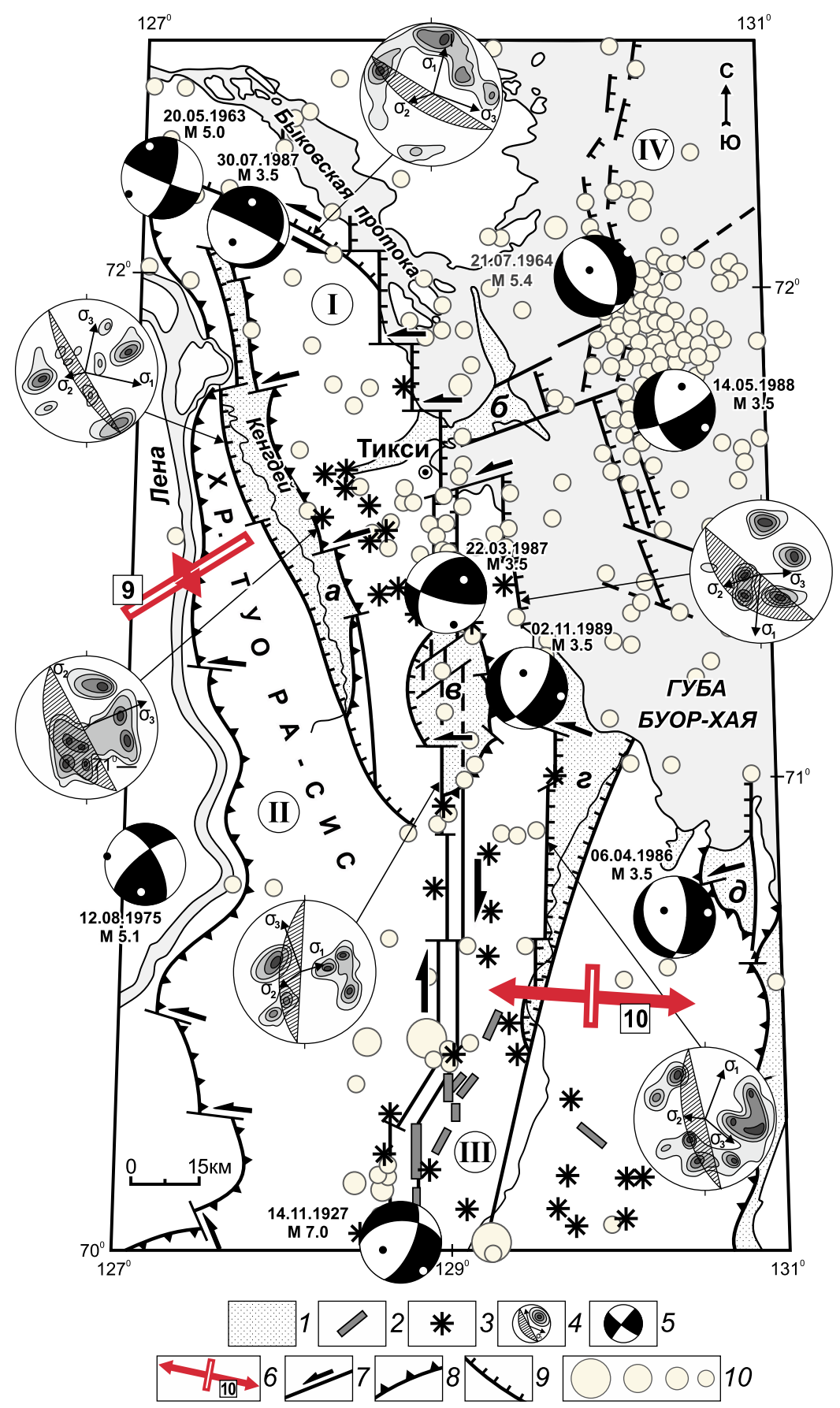

Рис. 4. Схема сейсмотектоники Хараулахского сегмента.

1 - кайнозойские впадины: $a$ - Кенгдейская, 6 - Хорогорская, в - Кунгинская, 2 - Хараулахская, $\partial$ - Няйбинская; 2 - сейсмодислокации; 3 - сейсмопроявления; 4 - диаграммы трещиноватости горных пород с положением векторов главных осей напряжений и плоскости разлома; 5 - фокальные механизмы землетрясений с указанием даты их возникновения и магнитуды (нижняя полусфера, выходы осей главных напряжений сжатия и растяжения обозначены черными и белыми точками); 6 - горизонтальная проекция главных осей деформаций (растяжения, сжатия) с указанием номера области расчета СТД (табл. 1). 7-9 - кинематика активных разломов: 7 - сдвиги, 8 - надвиги, 9 - сбросы; 10 - эпицентры землетрясений, соответственно с магнитудой $(M): \geq 6.8$, 5.0-6.7, 4.9-4.0, $\leq 3.9$ (данные ЯФ ГС СО РАН и ГС РАН). Система активных разломов: I - Приморская, II - Западно-Верхоянская, III - Хараулахская, IV - Буорхаинская.

Fig. 4. Seismotectonics of the Kharaulakh segment.

1 - Cenozoic depression: $a$ - Kengdey, $\sigma$ - Khorogor, $в$ - Kunga, 2 - Kharaulakh, $\partial$ - Nyaybinskaya; 2 - seismodislocations; 3 - seismic features; 4 - rock fracturing diagrams, positions of vectors of the principal stress axes and fault planes; 5 - focal mechanisms, dates and magnitudes of earthquakes (lower hemisphere; the axes of the principal compressional and extensional stresses are marked by black and white dots); 6 - horizontal projections of the principal strain axes (extension, compression) and numbers of the areas for STD calculations (see Table 1); 7-9 - kinematics of active faults: 7 - strike-slip faults, 8 - thrusts, 9 - normal faults; 10 - earthquake epicenters grouped by magnitude: $\geq 6.8,6.7-5.0,4.9-4.0, \leq 3.9$ (data published by the Geophysical Survey of the Russian Academy of Sciences (GS RAS) and its Yakutian branch). Systems of active faults: I - Primorskaya, II - West Verkhoyansk, III - Kharaulakh, IV - Buorkhainskaya. 
геолого-структурных полевых наблюдений, а также параметрами сейсмотектонических деформаций, рассчитанными по механизмам очагов землетрясений (см. рис. 2, 4).

По данным СТД в Хараулахском сегменте установлены две области с переходным типом деформационных режимов (от вертикального режима к сжатию и растяжению). Первая расположена в пределах Чекуровской антиклинали северо-западного фланга Верхоянской складчатой системы (группа 9 в табл. 1). Вторая наблюдается в южной части Хараулахской сбросо-сдвигой зоны (группа 10 в табл. 1). Следует заметить, что система напряжений в очаге Булунского землетрясения с $M \geq 7.0$ не совпадает с субдолготной и субширотной ориентацией главных осей деформаций сжатия и растяжения (рис. 4), что, возможно, обусловлено невысокой точностью определения фокального механизма данного события [Fujita et al., 2009].

Сейсмотектоническая зона Черского объединяет несколько перикратонных террейнов, примыкающих с востока к Верхоянскому складчато-надвиговому поясу, а также ряд террейнов, расположенных к северо-западу от Колымо-Омолонского блока [Parfenov et al., 2001]. По особенностям парагенезисов активных структур [Imaev et al., 2000], строению геофизических полей [Suvorov, Kornilova, 1986; Fujita et al., 2009], а также определенной закономерности сейсмического режима [Imaev et al., 2000; Imaeva et al., 2009, 2011] в сейсмотектонической зоне Черского выделяются Яно-Индигирский и Индигиро-Колымский региональные сегменты (рис. 5).

Геолого-структурные, морфотектонические и сейсмологические исследования показали (см. рис. 2), что в зоне Черского развиты активные разломы различного ранга и генезиса, большинство из которых сформировались в условиях горизонтального сжатия [Imaev et al., 2000]. На это указывают структурно-геологические наблюдения за характером смещения геологических тел в зонах разломов, исследования тектонической трещиноватости горных пород, интенсивная дислоцированность кайнозойских осадков [Gusev, 1979; Imaev et al., 2000]. Режим сжатия подтверждается также решениями фокальных механизмов сильных землетрясений, произошедших в зонах влияния активных разломов (см. рис. 2, 5).

Напряженное состояние земной коры сейсмотектонической зоны Черского исследовано на основе решений механизмов очагов землетрясений, произошедших во фронтальной зоне взаимодействия Колымо-Омолонского блока с Евразийской плитой. Для землетрясений зоны Черского характерно то, что они происходят в условиях устойчивого северо-восточного сжатия. При этом сжимаю- щие усилия близгоризонтальны (углы падения

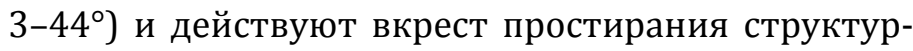
ных элементов территории. Напряжения растяжения часто совпадают по простиранию с линиями разломов и ориентированы как горизонтально, так и близвертикально (углы падения 2-85². Оси промежуточного напряжения имеют беспорядочную пространственную ориентацию и широкий интервал углов падения - от $0^{\circ}$ до $82^{\circ}$. Такая ориентация напряжений в очагах землетрясений господствует на всем протяжении зоны Черского.

Большинство фокальных механизмов землетрясений сейсмотектонической зоны Черского соответствует взбросам, надвигам и сдвигам (см. рис. 2). Из 24 определений $40 \%$ составляют взбросы, $30 \%$ - сдвиги, $20 \%$ - надвиги, а остальные $10 \%$ - сочетание сдвигов и сбросов. Такое соотношение очагов разного типа свидетельствует о том, что сейсмический процесс во фронтальной зоне взаимодействия Североамериканской и Евразийской плит протекает в условиях сжатия и является следствием движений по системе генеральных сдвигов, сопряженных с краевыми надвигами и взбросами.

Для сейсмотектонической зоны Черского характерно одновременное развитие продольных почти параллельных сдвигов разного знака - правосторонних в северо-западном (Яно-Индигирском) и левосторонних в юго-восточном (Индигиро-Колымском) сегментах. Такое сочетание сдвигов можно связать с наличием движущегося в юго-западном направлении индентора (Колымо-Омолонского блока), находящегося во фронтальной части Североамериканской плиты [Imaeva et al., 2009, 2015b, $2016 b]$. Под воздействием индентора континентальная часть Охотоморской плиты, представленная Индигиро-Колымским сегментом, смещается к востоку и юго-востоку, что подтверждается геоморфологическими данными [Imaeva et al., 2009, 2011, 2016b].

Данная кинематическая модель подтверждается закономерным изменением пространственной ориентации главных осей СТД (см. рис. 2). В ЯноИндигирском сегменте (группы 11-13 в табл. 1) проявлены три группы максимумов сейсмической активности. Для центральной области ПолоусноДебинской складчатой системы (группа 11 в табл. 1) выявлен переходный режим СТД - от сдвига к сжатию с субгоризонтальной осью сжатия северо-восток - юго-западной ориентации и субширотным растяжением. В Андрей-Тасском блоке (группа 12 в табл. 1) отчетливо проявляется режим сжатия с ориентацией оси сжатия также в северовосток - юго-западном направлении. Аналогичный тип СТД характерен и для Адыча-Тарынской шовной зоны (группа 13 в табл. 1). 


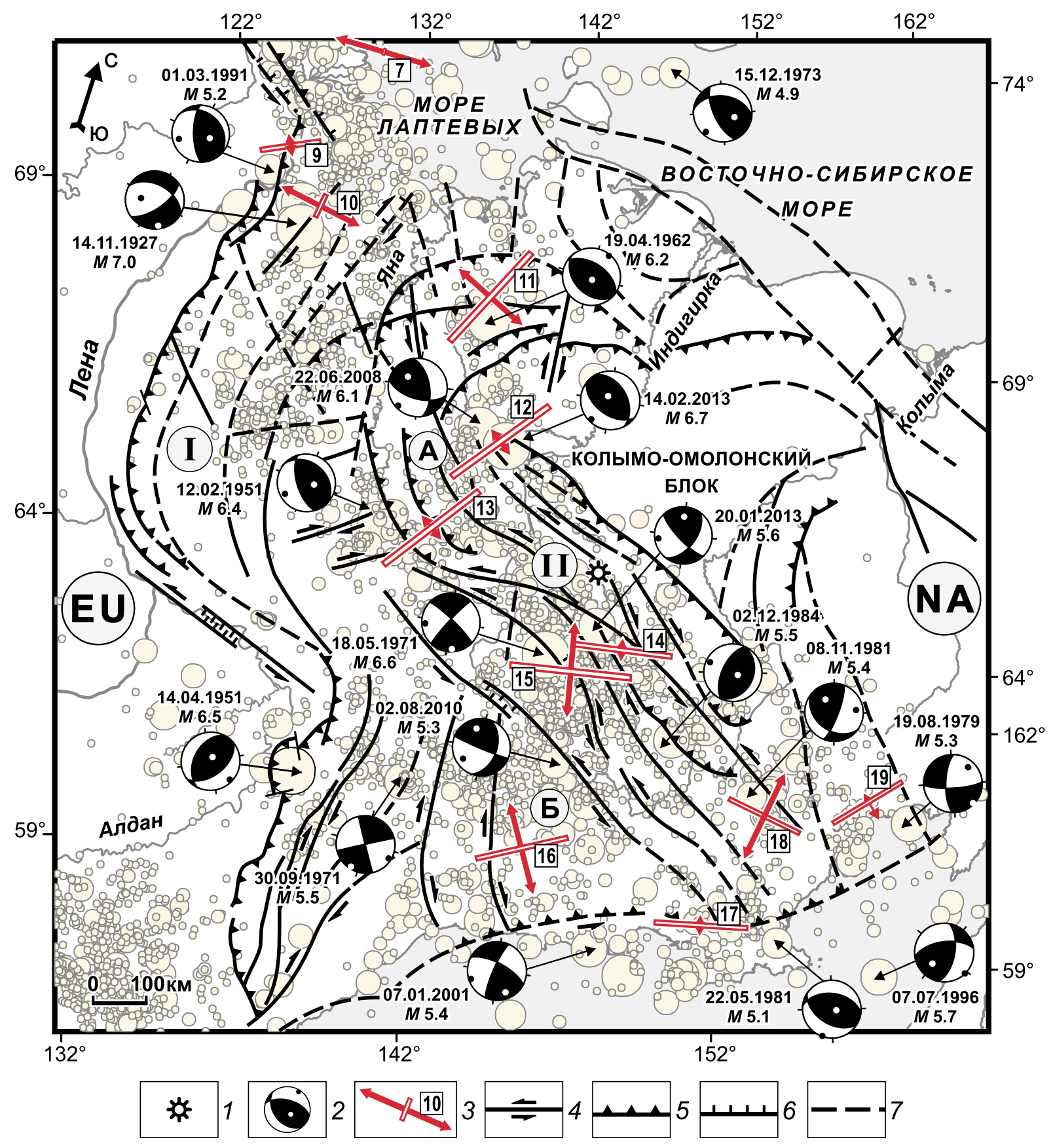

Эпицентры землетрясений с магнитудой (M):

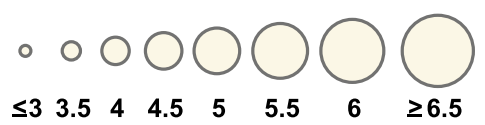

Рис. 5. Схема сейсмотектоники зоны Черского.

1 - вулкан Балаган-Тас; 2 - фокальные механизмы землетрясений с указанием даты их возникновения и магнитуды (нижняя полусфера, выходы осей главных напряжений сжатия и растяжения обозначены черными и белыми точками); 3 - горизонтальная проекция главных осей деформаций (растяжения, сжатия) с указанием номера области расчета СТД (табл. 1); 4-6 - кинематика активных разломов: 4 - сдвиги, 5 - надвиги и взбросы, 6 - сбросы; 7 - предполагаемые разломы. Литосферные плиты: ЕU Евразийская, NA - Североамериканская. I - Верхоянская складчатая система, II - сейсмотектоническая зона Черского: А - ЯноИндигирский сегмент, Б - Индигиро-Колымский сегмент.

Fig. 5. Seismotectonics of the Chersky zone.

1 - Balagan-Tas volcano; 2 - focal mechanisms, dates, and magnitudes of earthquakes (lower hemisphere; the axes of the principal compressional and extensional stresses are marked by black and white dots); 3 - horizontal projections of the principal strain axes (extension, compression) and numbers of the areas for STD calculations (Table 1); 4-6 - kinematics of active faults: 4 - strike-slip faults, 5 - thrusts and reverse faults, 6 - normal faults; 7 - assumed faults. Lithospheric plates: EU - Eurasian, NA - North American. I - Verkhoyansk fold system, II - Chersky seismotectonic zone: A - Yana-Indigirka segment, B - Indigirka-Kolyma segment. 
В центральной части сейсмотектонической зоны Черского ось сжатия меняет простирание на субширотное (группа 14 в табл. 1; рис. 5). В ЧайЮреинской сдвиговой зоне (группа 15 в табл. 1) господствует сдвиговый режим СТД с субширотным сжатием и субмеридиональным растяжением.

Для динамики сейсмогенерирующих структур Индигиро-Колымского сегмента (группы 14-19 в табл. 1) наиболее показательны тенденции напряженно-деформированного состояния земной коры Охотско-Кухтуйского блока (группа 16 в табл. 1), где отмечается сдвиговый режим. Механизм очага местного сильного события с $M_{\mathrm{w}}=5.3$ подтверждает кинематический тип движений по структурным ограничениям сегмента, который под воздействием сжимающих усилий выталкивается к юговостоку и востоку. Южное ограничение ИндигироКолымского сегмента, выраженное Челомджа-Ямским разломом, характеризуется переходным деформационным типом СТД: от вертикального режима к субширотному сжатию (группа 17 в табл. 1).

Остальные области расчета СТД, сконцентрированные на юго-восточном фланге зоны Черского, характеризуются параметрами деформаций, не согласующимися с системами напряжений в очагах наиболее сильных событий (группа 18-19 в табл. 1). Возможно, это связано с взаимным влиянием сейсмогенерирующих структур Арктико-Азиатского и Охотско-Чукотского сейсмических поясов. Таким образом, результаты сейсмологических исследований в целом подтверждают кинематическую модель формирования сейсмогенерирующих структур зоны Черского [Imaeva et al., 2009, 2011, 2016b].

Корякский сегмент. Согласно кинематической модели движения плит северо-востока Азии (рис. 1), ограничение с запада Беринговоморской плиты в пределах Корякского сегмента имеет конвергентный характер с правосдвиговой составляющей. В пределах сегмента развита система крупных взбросов-сдвигов северо-восточного простирания, современная активность которых определяется крупными сейсмическими событиями 1988, 1991 и 2006 гг. Их фокальные механизмы также подтверждают взбросовую природу этих землетрясений [Lander et al., 1996, 2007; Mackey et al., 1997].

Нами исследовались типы сейсмотектонических деформаций в пределах эпицентральной зоны Олюторского землетрясения, которое произошло 20 апреля 2006 г. с магнитудой $M_{\mathrm{w}}=7.6$ (рис. 6). Это сильнейшее за инструментальный период наблюдений межплитовое событие северо-западной окраины Берингова моря. Эпицентральная область располагалась в зоне хребтов Корякского нагорья: Пылгинского и Ветвейского. Главной особенностью землетрясения явился выход его очага на дневную поверхность в виде разнообразных по кинематике сейсморазрывов общей длиной порядка 140 км. Амплитуды вертикальных смещений в зоне разрыва достигали 2-3 м, а горизонтальных сдвиговых - 1.5 м [Pinegina, Konstantinova, 2006; Pinegina, 2007; Rogozhin et al., 2007, 2009].

Очаг Олюторского землетрясения обладает сложной и неоднородной структурой. Механизм подвижки вдоль магистрального сейсморазрыва изменяется от чистого взброса и взбросо-сдвига до сдвига со сбросовой компонентой. На большей части сейсморазрыва сдвиговые смещения правосторонние. В области главного эпицентра происходит смена преобладающего типа подвижки. Юго-западнее эпицентра наблюдаются в основном правые сдвиги, севернее и северо-восточнее преобладают взбросовые движения

В плейстосейстовой области широко представлены вторичные нарушения в виде сейсмогравитационных дислокаций и сейсмовибрационных деформаций. Сейсмовибрационные деформации в эпицентральной зоне проявились практически повсеместно в виде вторичных трещин с излияниями разжиженного грунта, просадок, грязевых вулканчиков. Гравитационные явления представлены не столь широко. Были отмечены обвалы и осыпи на крутых склонах в окрестности первичного сейсморазрыва. Область, охваченная вторичными сейсмодислокациями, имеет форму овала, вытянутого в северо-восточном направлении и длиной порядка 160 км. Ширина овала составляет 50-60 км [Pinegina, Konstantinova, 2006; Pinegina, 2007; Rogozhin et al., 2007, 2009].

Решения механизмов очагов Олюторского землетрясения и его афтершоков, заимствованные из международных сейсмологических центров [International Seismological Centre, 2017; Department..., 2017; Global Centroid Moment Tensor Project..., 2017; National Earthquake Information Center..., 2017] и литературных источников [Lander et al., 2007; Fujita et $a l ., 2009]$, позволяют отнести все механизмы к двум типам: взбросам и сдвигам. С учетом выбора предпочтительных плоскостей разрыва встречаются как правые, так и левые сдвиги. Надежные сбросы среди решений отсутствуют. В северо-восточной части очаговой зоны преобладают взбросовые движения, хотя встречаются и сдвиги различных направлений. В юго-западной части зоны, наоборот, сдвиговые подвижки (также обоих типов) встречаются чаще взбросов.

Параметры СТД, рассчитанные для Корякского сегмента по механизмам очагов 34 землетрясений, позволили выявить закономерную смену тектонических режимов в отдельных блоках (группы $22^{1}-22^{3}$ в табл. 1). Здесь практически одновременно присутствуют три режима СДТ (рис. 6). Основ- 

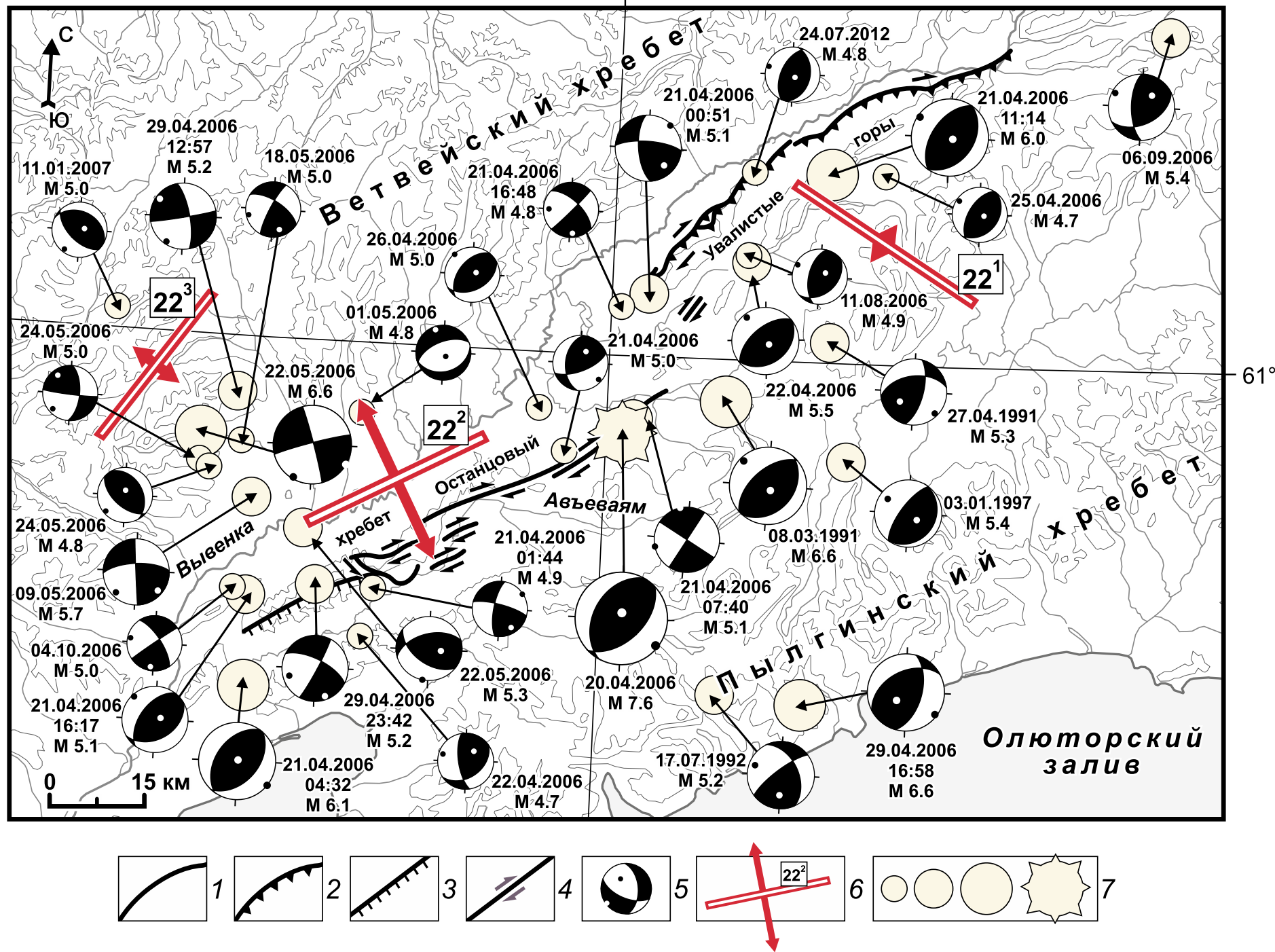

Рис. 6. Схема сейсмотектоники Корякского сегмента (по [Pinegina, 2007; Rogozhin et al., 2009] с изменениями и дополнениями).

1 - разрывные нарушения, в основном сдвиги; 2 - взбросо-надвиги, бергштрихи направлены в сторону поднятого крыла; 3 сейсмогравитационные дислокации (в виде уступа, прослеживающегося в подножии гряды), бергштрихи направлены в сторону опущенного крыла; 4 - направление сдвигового перемещения; 5 - фокальные механизмы землетрясений с указанием даты их возникновения и магнитуды (нижняя полусфера, выходы осей главных напряжений сжатия и растяжения обозначены черными и белыми точками); 6 - горизонтальная проекция главных осей деформаций (растяжения, сжатия) с указанием номера области расчета СТД (табл. 1); 7 - эпицентры землетрясений, соответственно с магнитудой $(M): 4.1-5.0,5.1-6.0,6.1-7.0, \geq 7.0$ (данные ЯФ ГС СО РАН и ГС РАН).

Fig. 6. Seismotectonics of the Koryak segment (modified after [Pinegina, 2007] and [Rogozhin et al., 2009]).

1 - faults (mainly strike-slip); 2 - overthrusts (bergstrichs are directed towards the upper wings); 3 - seismogravitational dislocation (a wedge traceable at the foot of the ridge) (bergstrichs are directed towards the lower wings); 4 - direction of shearing; 5 - focal mechanisms, dates and magnitudes of earthquakes (lower hemisphere; the axes of the principal compressional and extensional stresses are marked by black and white dots); 6 - horizontal projections of the principal strain axes (extension, compression) and numbers of the areas for STD calculations (Table 1); 7 - earthquake epicenters grouped by magnitude: 4.1-5.0, 5.1-6.0, 6.1-7.0, $\geq 7.0$ (data published by the Geophysical Survey of the Russian Academy of Sciences (GS RAS) and its Yakutian branch).

ной из них характеризуется юго-восток - северозападным сжатием, в режиме которого сформировался очаг сильнейшего Олюторского землетрясения с $M_{\mathrm{w}}=7.6$. В зоне хребта Останцовый при субгоризональных сжимающих усилиях и субгоризо- нальном растяжении выявлен сдвиговый режим СТД (группа $22^{2}$ в табл. 1). Менее масштабное деформационное поле в эпицентральной области Олюторского землетрясения представлено еще одним режимом сжатия, но с северо-восток - юго- 
западной ориентацией оси сжатия. Следует отметить, что поля напряжений и деформаций, которые одновременно существуют в Корякском блоке, являются производными от главного типа тектонического режима данного фрагмента плитной границы (см. рис. 1) и согласно «иерархии уровней» [Myachkin et al., 1982] их можно представить как бы «вложенными» одно в другое. Таким образом, параметры сейсмотектонических деформаций, рассчитанные по сейсмологическим данным, и кинематика поверхностных сейсморазрывов выявили общие тенденции в распределении полей напряжений земной коры Корякского сегмента.

Чукотский сегмент представляет собой северную границу Беринговоморской малой литосферной плиты. Современная тектоническая позиция, проявления сейсмичности и кинематический тип сейсмотектонических деформаций региона связаны с образованием в позднем мезозое рифта Берингова моря [Nakamura et al., 1980; Mackey et al., 1997; Nokleberg et al., 2000; Parfenov et al., 2001]. Рифт представляет собой зону растяжения, которая возникла между окончаниями двух крупных систем взбросов и правых сдвигов на Корякском нагорье - Чукотке и правых сдвигов Западной Аляски (см. рис. 1). По данным инструментальных сейсмологических и геолого-структурных исследований [Dumitru et al., 1995], зона растяжения продолжается от полуострова Сьюард на шельф Берингова моря к Чукотке. Сложная система сбросовых уступов выявлена также в Беринговом море южнее полуострова Сьюард [Toro et al., 2003].

История геологического развития и современный структурный план Восточной Чукотки и Западной Аляски свидетельствует о том, что остров Врангеля в Восточно-Сибирском море, восточная часть Чукотского полуострова, полуостров Сьюард и горные хребты на Аляске сложены примерно однородными по составу и сходными по возрасту горными породами. Они входят в структуру единого композиционного Арктического террейна и образуют обращенный к югу Беринговоморский ороклин, который возник в позднемезозойское время (поздняя юра - неоком) [Nakamura et al., 1980; Nokleberg et al., 2000]. В процессе конвергенции Тихоокеанской и Североамериканской плит в кайнозое в пределы Аляски «внедрился» индентор Тихоокеанской плиты с вершиной, направленной на северо-запад и запад к указанному ороклину.

Максимальное влияние сжимающих усилий со стороны Тихоокеанской плиты сказывается на траектории максимальной концентрации эпицентров землетрясений, которая фиксируется в направлении от Аляски к Чукотке [Mackey et al., 1997; Imaev et al., 2000; Parfenov et al., 2001]. Здесь наиболее активным является Колюченско-Мечигменский район, в пределах которого за последние 70 лет отмечено свыше 100 землетрясений, шесть из них имели $M=5.0-6.9$ (см. рис. 2; рис. 7). Группа сейсмических событий, сконцентрированная около Колючинского залива, прослеживается на юго-восток в направлении к заливу Провидения. Здесь в 1928 г. произошли четыре сильных землетрясения с магнитудой 6.2-6.9. Определенная закономерность в распределении землетрясений наблюдается в направлении от Колючинского залива в Чукотское море, где в 1962, 1971 и 1996 гг. зафиксированы землетрясения с магнитудой M=5.0-6.0 [Fujita et al., 2002].

Влияние горизонтальных растягивающих тектонических напряжений устанавливается также на Чукотском полуострове. Это выражается в развитии местных сбросов северо-западного простирания в сочетании со сдвигами, которые ограничивают морфологически отчетливо выраженные неоген-четвертичные впадины Колючинско-Мечигменской зоны растяжения. Высокая сейсмическая активность этого района и фокальные механизмы сильных землетрясений, указывающие на сбросовый характер движения в их очагах (землетрясения 1962, 1971 и 1996 гг.), свидетельствуют о преобладании здесь сейсмического режима, характерного для рифтовых зон [Fujita et al., 2002].

В 2003 г. группой сейсмологов Мичиганского университета (США) совместно с сотрудниками Магаданской опытно-методической сейсмологической партии Геофизической службы РАН были проведены комплексные сейсмологические исследования в районе пос. Нешкан, где в 1996 г. произошло землетрясение с магнитудой $M=6.0$. Исследования проводились на побережье Чукотского моря в пределах восточной части Колючинской неотектонической впадины (рис. 7). Материалами морских сейсмических работ здесь установлено существование разлома, ограничивающего зону опускания Колючинского залива [Aksenov et al., 1987], который является частью огромной системы кайнозойских рифтов, находящихся в южной части Чукотского моря. Рифтовая система прослеживается до меридиана Колючинского залива, где резко обрывается, и не прослеживается далее на запад. По данным морской сейсморазведки методом отраженных волн в четвертичных отложениях фиксируется вертикальный разлом с амплитудой смещения 40 м [Eittreim et al., 1979; Shipilov, 1989].

Фокальные механизмы землетрясений, зафиксированные в районе пос. Нешкан, свидетельствуют о правостороннем сдвиге по плоскости северовосточной ориентации. По другой нодальной плоскости, которая почти параллельна береговой линии, определяется режим растяжения. Это совпадает с ранее полученными данными, где установлено северо-восточное простирание разломов по- 


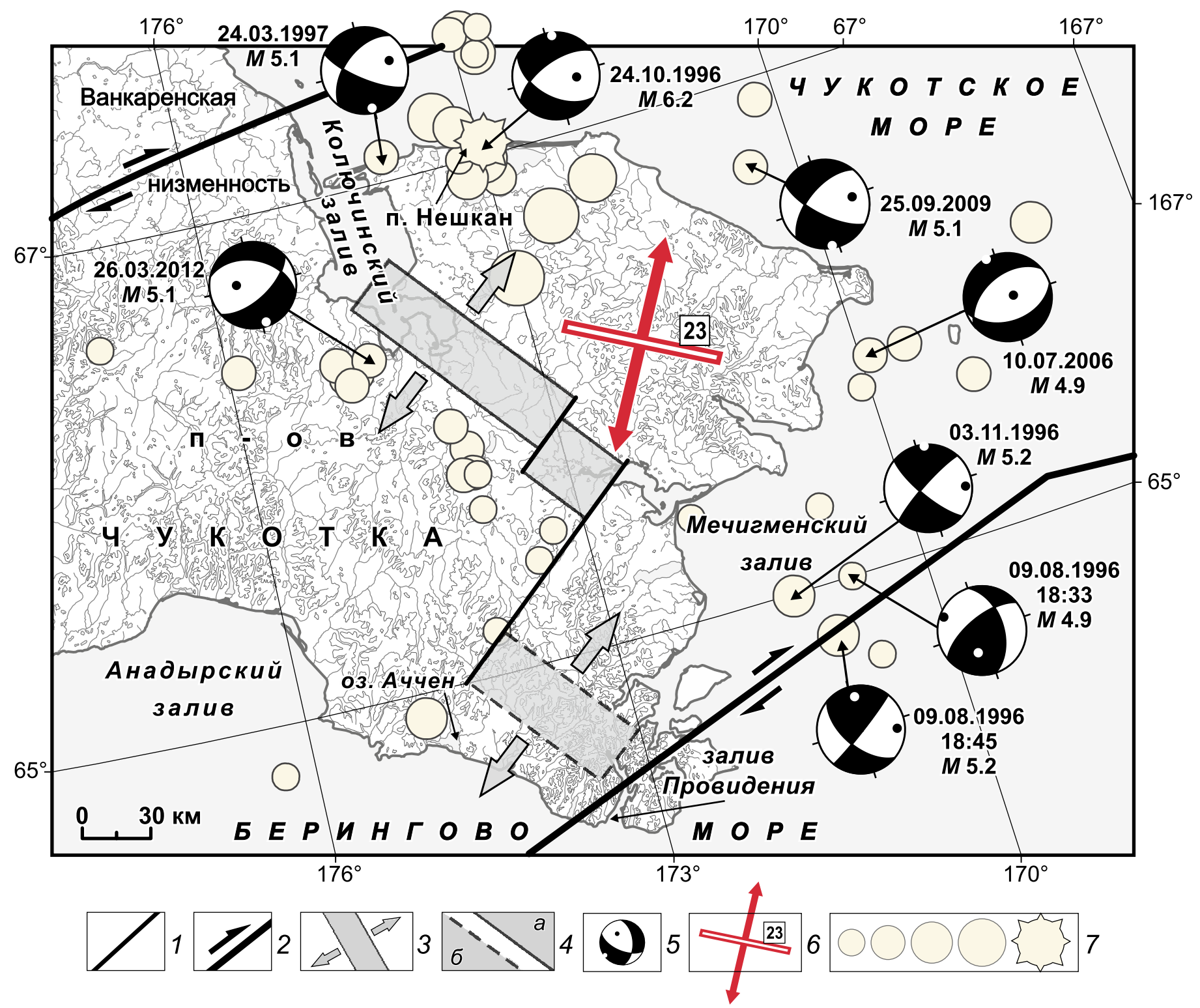

Рис. 7. Схема сейсмотектоники Чукотского сегмента (по [Mackey et al., 1997], с изменениями и дополнениями).

1 - трансформный разлом; 2 - активные сдвиги; 3 - направление растяжения; 4 - рифтовые структуры: а - установленные, б предполагаемые; 5 - фокальные механизмы землетрясений с указанием даты их возникновения и магнитуды (нижняя полусфера, выходы осей главных напряжений сжатия и растяжения обозначены черными и белыми точками); 6 - горизонтальная проекция главных осей деформаций (растяжения, сжатия) с указанием номера области расчета СТД (табл. 1); 7 - эпицентры землетрясений, соответственно с магнитудой $(M): 2.5-3.7,3.8-4.3,4.4-5.2,5.3-6.1,6.2-7.0$ (данные ЯФ ГС СО РАН и ГС РАН).

Fig. 7. Seismotectonics of the Chukotka segment (modified after [Mackey et al., 1997]).

1 - transform fault; 2 - active strike-slip faults; 3 - direction of tension; 4 - rift structures: a - identified, 6 - assumed; 5 - focal mechanisms, dates, and magnitudes of earthquakes (lower hemisphere; the axes of the principal compressional and extensional stresses are marked by black and white dots); 6 - horizontal projections of the principal strain axes (extension, compression) and numbers of the areas for STD calculations (see Table 1); 7 - earthquake epicenters grouped by magnitude: 2.5-3.7, 3.8-4.3, 4.4-5.2, 5.3-6.1, 6.2-7.0 (data published by the Geophysical Survey of the Russian Academy of Sciences (GS RAS) and its Yakutian branch).

добной кинематики, являющихся трансформными между смещенными сегментами рифтов [Fujita et al., 2002; Toro et al., 2003].

На территории Чукотского сегмента (группа 23 в табл. 1) режим СТД характеризуется переходом от сдвига к растяжению, а направление осей дефор- маций представлено северо-восток - юго-западным субгоризонтальным растяжением и северо-запад юго-восточным наклонным сжатием.

Данные повторного нивелирования [Zolotorevskaya et al., 1987] свидетельствуют о том, что северное побережье Чукотского полуострова поднима- 
T а б л и ц а 2. Горизонтальные скорости GPS-пунктов относительно общеземного отсчетного основания ITRF2008

$\mathrm{T}$ a b l e 2. Horizontal velocities of GPS monitoring points relative to ITRF 2008

\begin{tabular}{|c|c|c|c|c|c|c|}
\hline \multicolumn{2}{|c|}{ Координаты пунктов наблюдений } & \multirow{2}{*}{$\begin{array}{l}\text { Скорость В-3, } \\
\text { мм/год }\end{array}$} & \multirow{2}{*}{$\begin{array}{l}\text { Скорость С-Ю, } \\
\text { мм/год }\end{array}$} & \multirow{2}{*}{$\begin{array}{l}\text { Ошибка В-3, } \\
\text { мм/год }\end{array}$} & \multirow{2}{*}{$\begin{array}{l}\text { Ошибка С-Ю, } \\
\text { мм/год }\end{array}$} & \multirow[t]{2}{*}{ GPS-пункт } \\
\hline$\lambda^{0} \mathrm{o}$ & $\varphi^{\underline{0}}$ & & & & & \\
\hline 8.36 & 69.362 & 22.13 & -2.09 & 0.2 & 0.21 & NRIL_GPS \\
\hline 104.316 & 52.219 & 25.21 & -6.65 & 0.22 & 0.31 & IRKJ_GPS \\
\hline 129.68 & 62.031 & 18.9 & -12.94 & 0.44 & 0.41 & YAKT_GPS \\
\hline 136.812 & 62.784 & 19.59 & -13.84 & 1.63 & 1.62 & TKL1_GPS \\
\hline 143.242 & 64.566 & 16.96 & -15.05 & 1.36 & 1.35 & UNR1_GPS \\
\hline 148.168 & 62.779 & 13.42 & -18.05 & 1.25 & 1.25 & SUS1_GPS \\
\hline 150.81 & 59.578 & 11.63 & -17.53 & 0.63 & 0.82 & MAGD_AVG \\
\hline 152.392 & 61.13 & 12.99 & -20.40 & 2.3 & 2.23 & TAL1_GPS \\
\hline 152.422 & 62.925 & 11.30 & -18.59 & 1.19 & 1.17 & SEY2_GPS \\
\hline 155.77 & 62.518 & 10.48 & -17.76 & 2.27 & 2.21 & OMS1_GPS \\
\hline 163.067 & 59.243 & 8.26 & -18.96 & 2.23 & 2.2 & OSSO_GPS \\
\hline 191.938 & 65.615 & -0.97 & -23.77 & 0.77 & 0.67 & AB09_GPS \\
\hline 193.799 & 60.385 & -4.91 & -22.58 & 0.87 & 0.87 & AB08_GPS \\
\hline 194.627 & 64.564 & -1.53 & -24.41 & 0.79 & 1 & AB11_GPS \\
\hline 195.433 & 65.554 & -1.86 & -23.91 & 0.93 & 0.86 & AC50_GPS \\
\hline 197.386 & 66.858 & -2.20 & -25.24 & 0.7 & 0.6 & AB18_AVG \\
\hline 198.158 & 60.788 & -3.80 & -23.46 & 0.57 & 0.67 & BET1_GPS \\
\hline 203.39 & 71.323 & -5.03 & -22.07 & 0.076 & 0.73 & SG27_AVG \\
\hline
\end{tabular}

П р и м е ч а н и е. AVG в названии пунктов GPS-наблюдений означает, что табличное значение скорости было получено в результате осреднения значений скоростей близкорасположенных пунктов.

$\mathrm{N}$ o t e. For the GPS monitoring points marked with AVG, tabulated velocity rates were calculated by averaging the velocity rates recorded at the neighbouring monitoring points.

ется со скоростью 0.6-2.3 мм/год, в то время как южная часть опускается со скоростью от 2 до 4 мм/год. К другим признакам рифта Берингова моря следует отнести расположение в его пределах ареалов позднекайнозойского щелочного вулканизма (Беринговоморская щелочно-базитовая провинция) и массовые проявления гидро- и газотермальной деятельности [Akinin, Apt, 1994], которые наблюдаются как на западном (Чукотка), так и на восточном (Западная Аляска) фланге рифта. Все эти данные в совокупности с геолого-геофизическими исследованиями свидетельствуют о доминировании на данной территории современного режима растяжения.

\section{4. СКОРОСТЬ ДЕФОРМАЦИЙ ПО ДАННЫМ GPS-ИЗМЕРЕНИЙ}

Для анализа были использованы значения скоростей горизонтальных смещений из обобщающей работы [Kreemer et al., 2014], в которой объединены материалы GPS-исследований по всему миру с собственным решением и в которую вошли также результаты работ [Steblov et al., 2003; Apel et al., 2006; Freymueller et al., 2008]. При дублировании скоростей GPS-пунктов, взятых из разных источников, а также для рядом расположенных пунктов были выбраны единственные значения скорости, исходя из следующих критериев: предпочтение отдавалось более поздней публикации; выбиралась скорость смещения GPS-пункта с наименьшей ошибкой; при незначительных расхождениях значений скоростей и ошибок для близко расположенных пунктов GPS принимались усредненные значения. Полученные значения современных горизонтальных скоростей приведены в таблице 2 и показаны на рисунке 8.

На основе поля скоростей современных горизонтальных движений были рассчитаны деформационные параметры региона с помощью программного пакета QOCA [Dong et al., 1998], а также методом, предложенным М. Хаклом с соавторами [Hackl et al., 2009]. В первом случае вся территория 

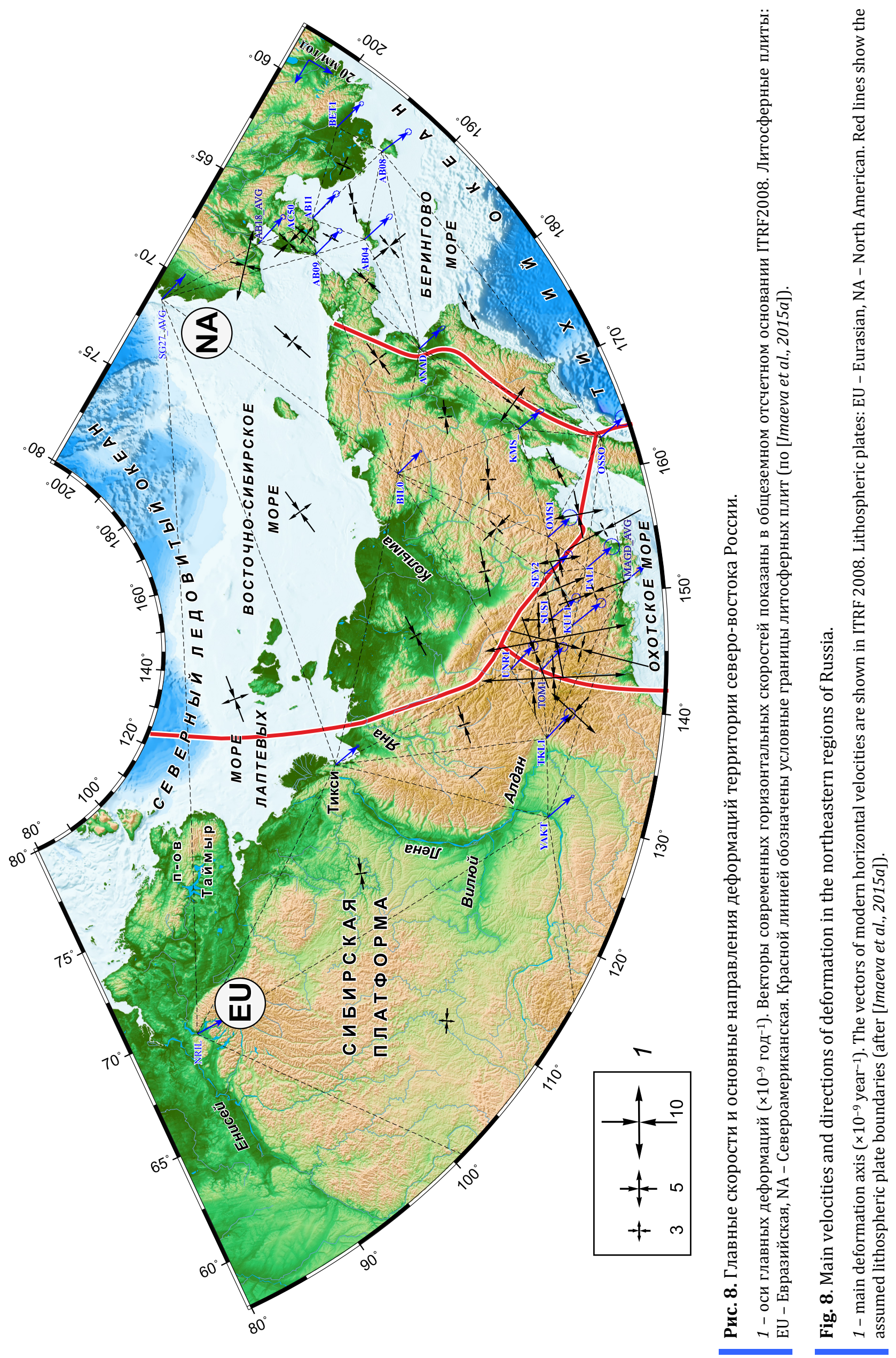
была разбита на триангуляционную сеть с пунктами GPS в вершинах треугольников. Для треугольников рассчитаны главные скорости деформаций, главные направления деформаций и скорость вращения (табл. 3, рис. 8, 9). В пределах каждого треугольника деформация считалась однородной. Результат расчетов зависит от размера полигона и равномерности распределения данных по площади.

Подход М. Хакла [Hackl et al., 2009] и соавторов имеет отличие от расчета деформаций методом Донга с соавторами [Dong et al., 1998]. Здесь авторы применили метод сплайн-интерполяции [Smith, Wessel, 1990]. Это простой и быстрый способ обработки геодезических данных для получения непрерывного поля скоростей с заданной дискретизацией. Для этого выполнялась сплайн-интерполяция широтной и долготной компонент скоростей с шагом 50 км. Получив непрерывное поле скоростей, мы рассчитали градиенты скоростей, то есть компоненты тензора скоростей деформаций. С помощью компонентов тензора скоростей деформаций для каждой ячейки размерностью 50×50 км были рассчитаны главные направления деформаций $\left(\alpha_{1}\right.$, $\left.\alpha_{2}\right)$ и главные скорости деформаций $\left(\dot{\varepsilon}_{1}, \dot{\varepsilon}_{2}\right)$ (рис. 10), скорость дилатации $(\dot{\delta})$ (рис. 10$)$, а также второй инвариант тензора скоростей деформаций $\left(\dot{I}_{2}\right)$ (рис. 11). Отметим, что этот метод не рассчитан на определение абсолютно точных значений скоростей деформаций, поскольку связан с градиентом поля скоростей и зависит от размера ячейки. Тем не менее метод надежен для определения изменения скорости и типа деформаций. Для минимизации краевых искажений при интерполяции рекомендуется включать в решение данные вне области исследования. Но мы, напротив, исключили значительно удаленные от региона исследований пункты GPS-наблюдений в городах Норильске (NRIL_GPS) и Иркутске (IRKJ_GPS), так как они могли еще сильнее исказить реальную картину. Примененные методы дополняют друг друга и позволяют верифицировать результаты. Первый метод дает точные значения параметров деформаций, но только для всего треугольника целиком. Преимущество второго в том, что он хорошо описывает пространственные изменения напряженно-деформированного состояния земной поверхности.

Сравнение результатов расчета скоростей деформаций на территории Российской Арктики показало, что два метода дают качественно идентичную картину и близкие количественные значения (см. рис. 8, 10). Практически для всей территории Евразийской и Североамериканской литосферных плит характерны низкие значения скоростей де-

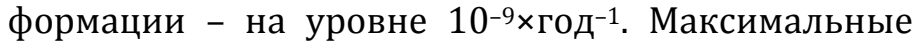
значения скоростей деформаций $\approx|3| \times 10^{-8} \times$ год $^{-1}$ получены для зоны сочленения Евразийской, Североамериканской и Охотоморской литосферных плит (табл. 3, см. рис. 8). Практически вся территория исследования характеризуется сокращением площади (отрицательная дилатация) с низкими скоростями, лишь отдельные области достигают значений $\approx-3 \times 10^{-8} \times$ год $^{-1}$. Небольшой фрагмент с близкими значениями скорости, но только расширения находится недалеко от тройного сочленения плит (см. рис. 10). Если исключить периферийные зоны, подверженные краевым искажениям при интерполяции, то второй инвариант тензора скоростей деформаций имеет те же максимальные значения $\approx 3 \times 10^{-8} \times$ год $^{-1}$ в области сочленения литосферных плит (рис. 11). Второй инвариант - это численное выражение общей скорости деформации, его можно представить как длину гипотенузы в прямоугольном треугольнике, где катетами являются оси главных деформаций. Граница между Североамериканской и Охотоморской плитами также проявлена в направлении вращения треугольников триангуляционной сети. На ней находится область вращения против часовой стрелки в обратном по сравнению с остальной территорией направлении (см. рис. 9).

\section{5. ГЛУБИННОЕ СТРОЕНИЕ ЗЕМНОЙ КОРЫ И ВЕРХНЕЙ МАНТИИ ПО СЕЙСМОЛОГИЧЕСКИМ ДАННЫМ}

В настоящем разделе представлен обзор имеющихся в литературе сведений о глубинном строении земной коры и верхней мантии северо-восточного сектора Российской Арктики. При сопоставлении результатов различных исследований учтена их разрешающая способность. На основании глобальных моделей приведены данные об анизотропных свойствах мантии. Рассмотренная информация имеет существенное значение для понимания геологических закономерностей и построения достоверных геодинамических моделей эволюции рассматриваемой территории.

Толщина земной коры исследуемой области, согласно глобальной модели CRUST 1.0 [Laske et al., 2013], варьируется в широких пределах: от 5 км в глубоководной части Северного Ледовитого океана (котловина Амундсена) до 50 км под Сибирской платформой (рис. 12). Следует отметить, что данная модель с учетом разрешения в пределах континентальной части рассматриваемой территории хорошо согласуется с результатами региональных исследований, выполненных различными методами [Suvorov et al., 1999; Cherepanova et al., 2013; Mackey et al., 1998]. Однако есть и отличия, в основном относящиеся к слабо обеспеченным сейсмологическими данными районам. Например, большая 


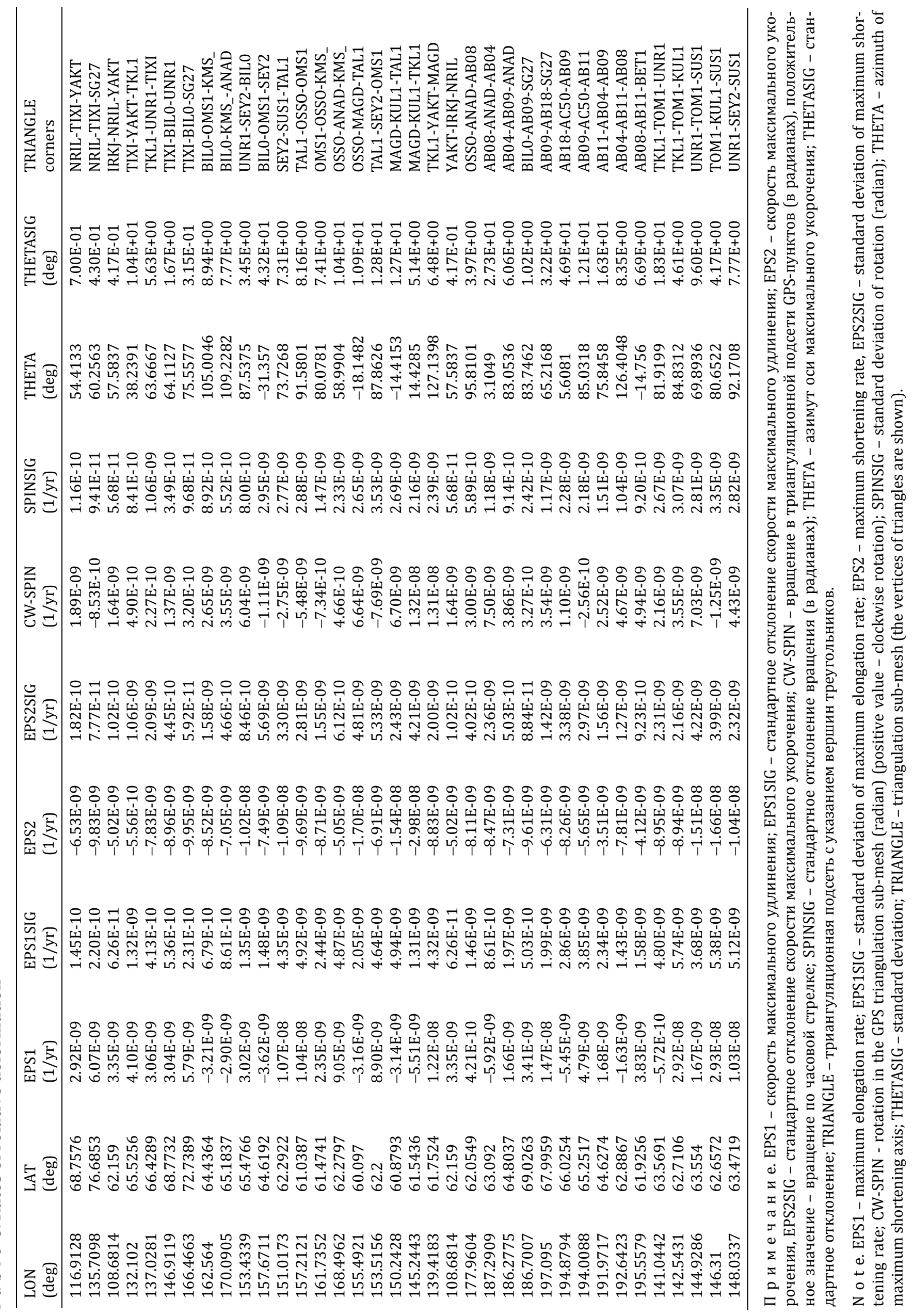



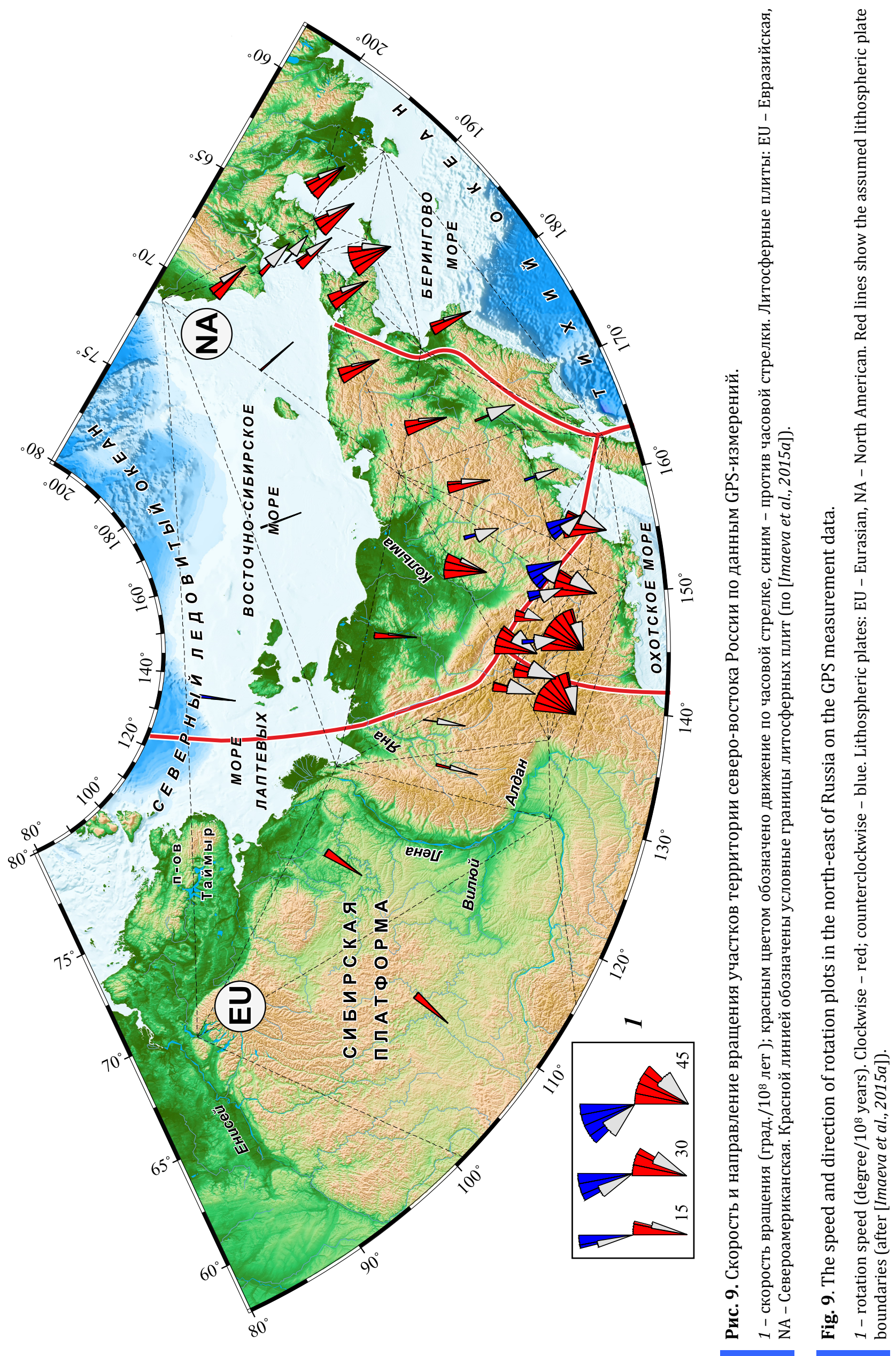

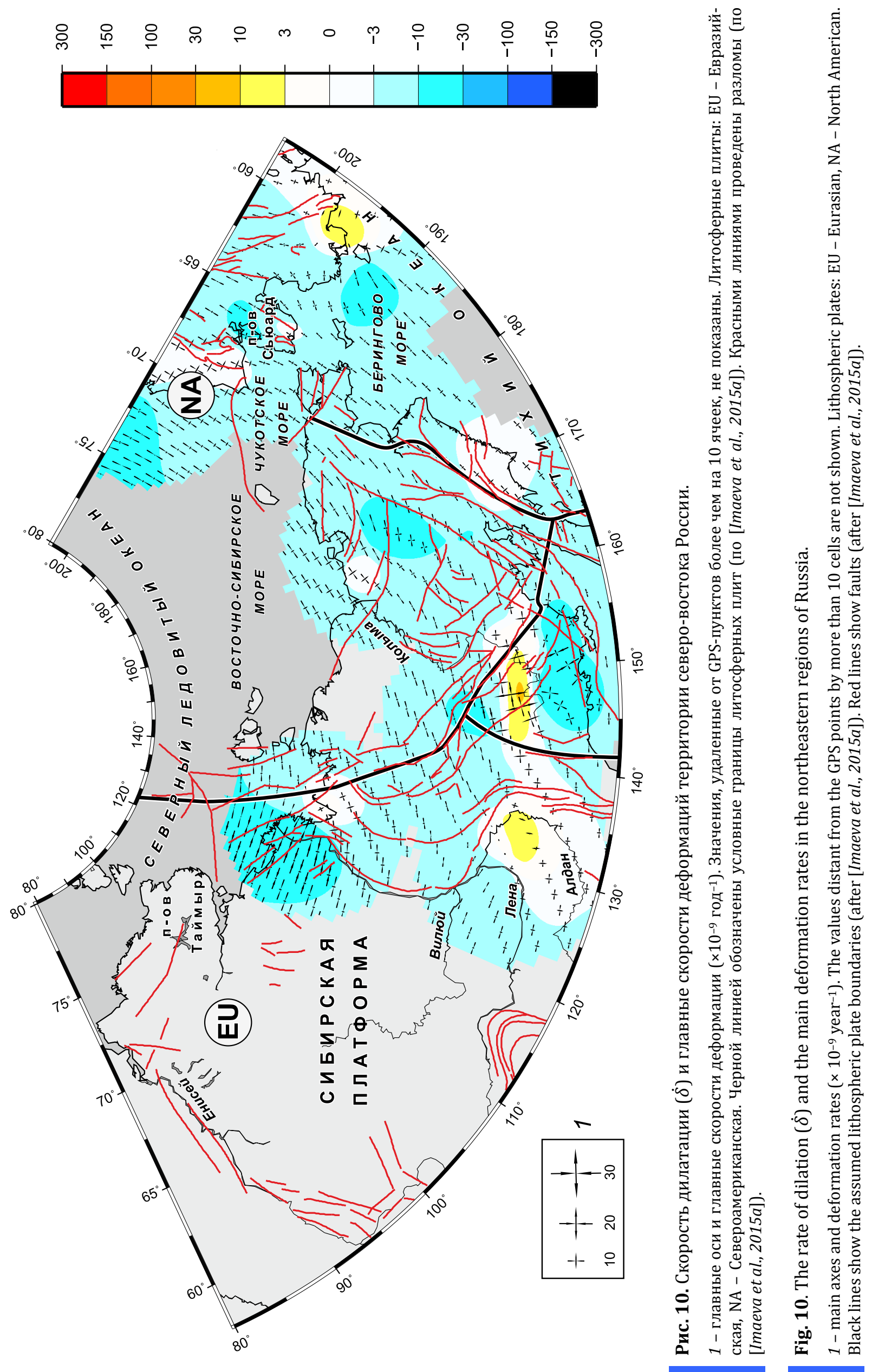


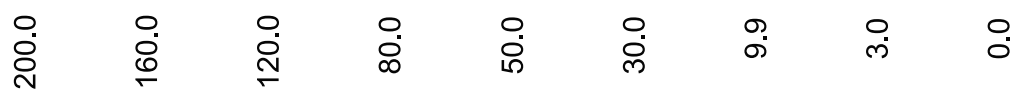
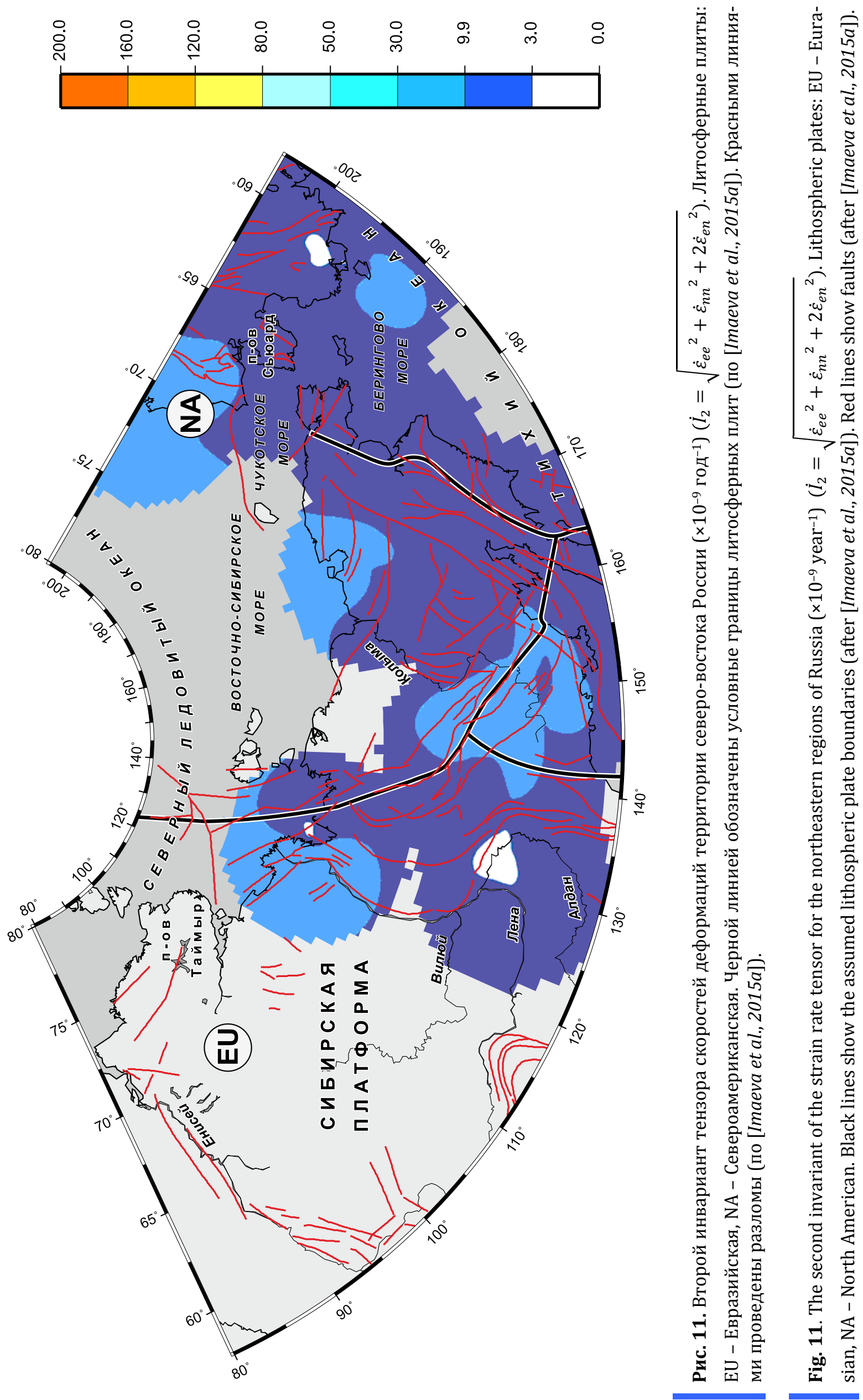


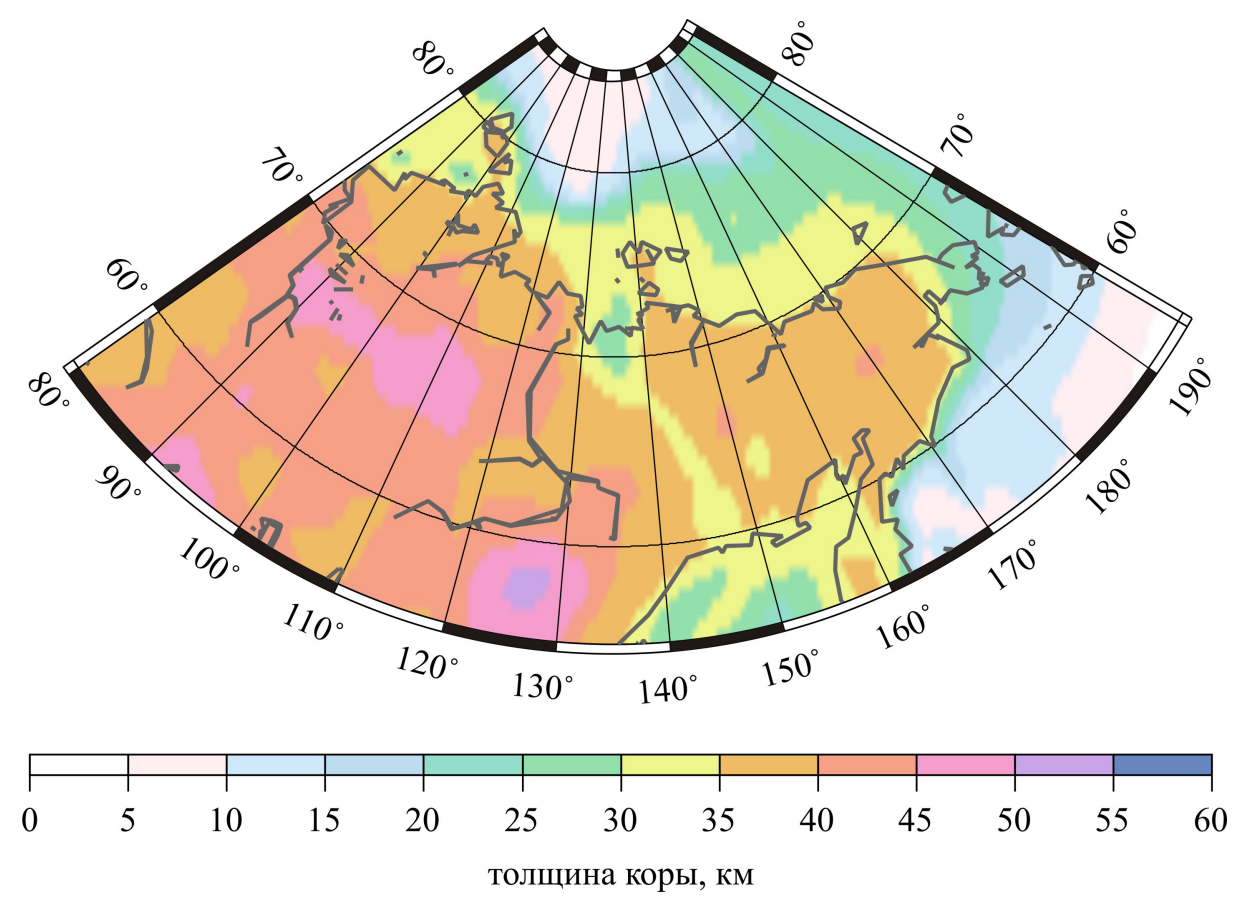

Pис. 12. Толщина коры согласно модели CRUST 1.0 [Laske et al., 2013].

Fig. 12. Thickness of the crust from CRUST 1.0 model [Laske et al., 2013].

часть Верхоянского складчатого пояса характеризуется мощностью коры 35-40 км, что не противоречит данным [Mackey et al., 1998] за исключением утонения коры до 30 км между Верхоянским хребтом и хребтом Черского. Кроме того, региональные исследования [Mackey et al., 1998] демонстрируют большее утонение коры в районе устья р. Яны, где ее мощность составляет менее 20 км.

Толщина коры под шельфами окраинных морей на севере Азиатского континента (Карское море, море Лаптевых и Восточно-Сибирское море) достигает 35 км и постепенно уменьшается в северном направлении. При имеющемся разрешении модель CRUST 1.0 не позволяет проследить вариации мощности под Северным Ледовитым океаном, выделенные ранее по данным сейсмопрофилирования. Согласно последним минимальное утонение коры (до 1.5 км) наблюдается под океаническими бассейнами и отдельными сегментами хребта Гаккеля [Jokat, Schmidt-Aursch, 2007], а максимальная мощность $\sim 32$ км отмечена под хребтом Менделеева [Lebedeva-Ivanova et al., 2006]. Повышенная толщина коры под последним, а также наличие хорошо выраженного гранитного слоя мощностью от 2 до 12 км позволяют предположить, что земная кора под хребтом относится к континентальному типу [Artyushkov, 2010; Lebedeva-Ivanova et al., 2006]. Однако существует и противоположное мнение, согласно которому это океаническая кора, образовавшаяся на горячих пятнах типа Исландского пятна в Атлантике или Онтонг Джава в Тихом океане [Lawver et al., 2002].

Исследования глубинного строения мантии рассматриваемой территории, выполненные на разномасштабном уровне (от регионального до глобальных моделей), свидетельствуют о наличии существенных горизонтальных неоднородностей. Максимальные значения скоростей как продольных [Jakovlev et al., 2012], так и поперечных волн [Shapiro, Ritzwoller, 2002; Schaeffer, Lebedev, 2013] до глубины около 250 км наблюдаются под Сибирской платформой, а минимальные приурочены к зонам субдукции. Мантия под бассейном Северного Ледовитого океана характеризуется относительно высокими скоростями сейсмических волн - до $\sim 150$ км, а с увеличением глубины - пониженными скоростями по отношению к прилегающим территориям, о чем также свидетельствуют особенности распределения групповых скоростей поверхностных волн [Levshin et al., 2001]. Практически все рассматриваемые модели демонстрируют локальный минимум скоростей, приуроченный к спрединговому хребту Гаккеля, причем с увеличением глубины данная особенность становится более выраженной [Zhou et al., 2006].

Кроме того, было показано, что вещество верхней мантии исследуемой области обладает анизотропными свойствами. При этом на глубинах до 250 км вертикальная анизотропия, проявляющаяся в различии скоростей волн SV и SH, поляризован- 


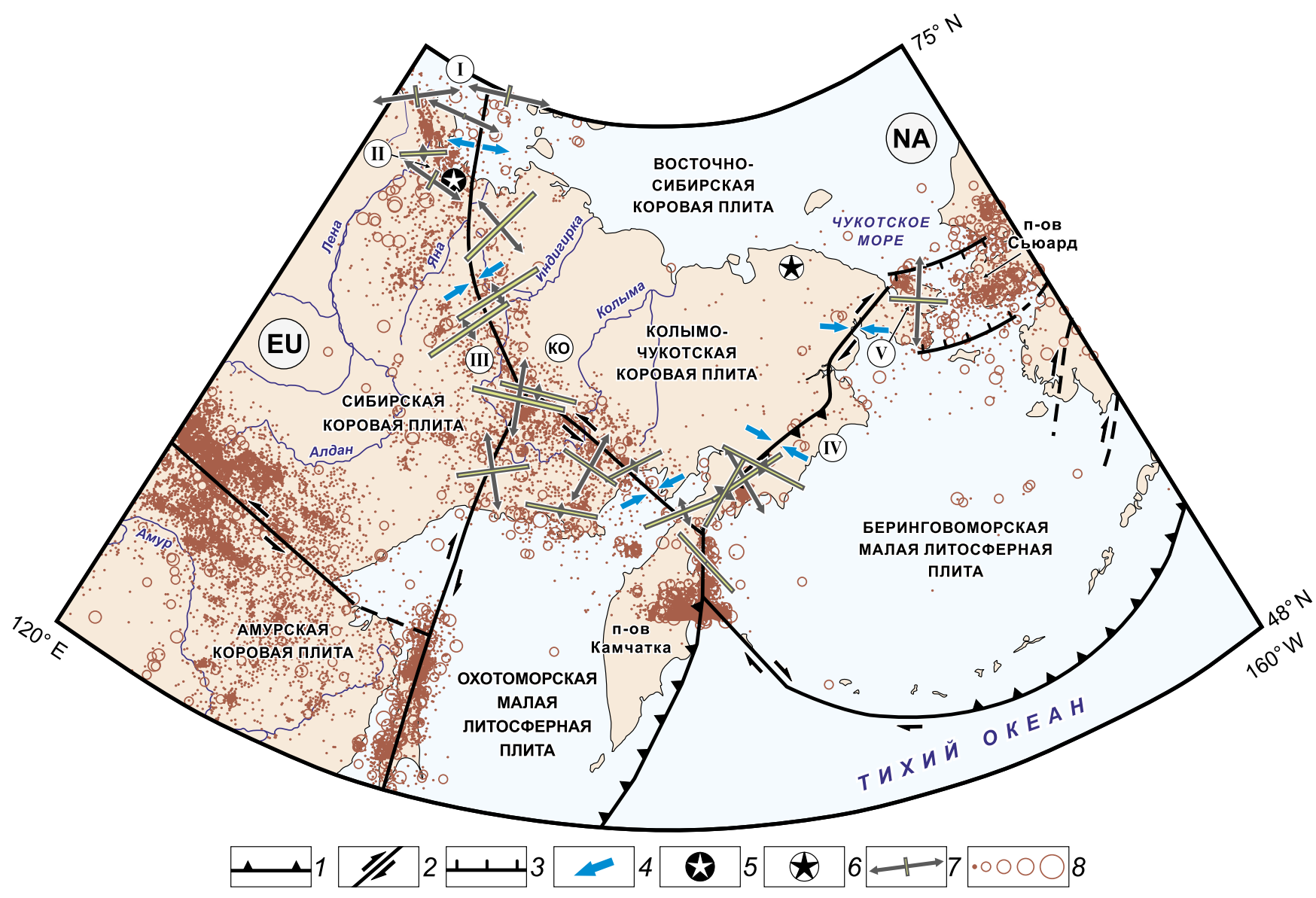

Рис. 13. Структурно-динамическая модель главных сейсмогенерирующих структур территории северо-востока Азии (по [Fujita et al., 2009] с изменениями и дополнениями).

1 - надвиги; 2 - границы плит с разным направлением относительных перемещений; 3 - сбросы; 4 - направление движения блоков по границе Колымо-Чукотской коровой плиты (по комплексу геолого-геофизических данных); 5 - местоположение полюса вращения Евразийской и Североамериканской плит; 6 - местоположение полюса вращения Беринговоморской малой литосферной плиты относительно Североамериканской; 7 - горизонтальная проекция главных осей деформаций (растяжения, сжатия); 8 - эпицентры землетрясений с магнитудой $(M)$, соответственно: $\leq 4.0,4.0-4.9,5.0-5.9,6.0-6.9$, $\geq 7.0$. Эпицентры землетрясений вдоль Алеутской и Курило-Камчатской вулканических дуг не показаны. Сегменты Арктико-Азиатского сейсмического пояса: I - Лаптевоморский, II - Хараулахский, III - сейсмотектоническая зона Черского. Сегменты Охотско-Чукотского сейсмического пояса: IV - Корякский, V - Чукотский. КО - Колымо-Омолонский блок. Литосферные плиты: EU - Евразийская, NA - Североамериканская.

Fig. 13. Structural-dynamic model of the main seismogenerating structures in Northeast Asia (modified after [Fujita et al., 2009]).

1 - thrusts; 2 - boundaries of plates with different directions of relative movements; 3 - normal faults; 4 - directions of block movements at the margin of the Kolyma-Chukotka crustal plate (based on the geological and geophysical data); 5 - position of the rotation pole of the Eurasian and North American plates; 6 - location of the rotation pole of the small Bering lithospheric plate with respect to the North American plate; 7 - horizontal projections of the principal strain axes (extension, compression); 8 - earthquake epicenters grouped by magnitude: $\leq 4.0,4.0-4.9,5.0-5.9,6.0-6.9, \geq 7.0$. Epicenters of earthquakes along the Aleutian and Kuril-Kamchatka volcanic arcs are not shown. Segments of the Okhotsk-Chukotka seismic belt: IV - Koryak, V - Chukotka. KO - Kolyma-Omolon block. Lithospheric plates: EU Eurasian, NA - North American.

ных в вертикальной и горизонтальной плоскостях, и получаемых путем интерпретации дисперсионных кривых волн Рэлея и Лява соответственно, является положительной [Shapiro, Ritzwoller, 2002; Zhou et al., 2006], а в интервале глубин 250-400 км проявляются достаточно обширные области, приуроченные к зонам субдукции и хребту Гаккеля, с отрицательной анизотропией $\left(\mathrm{V}_{\mathrm{SH}_{\mathrm{H}}}<\mathrm{V}_{\mathrm{SV}}\right)$, свидетель- ствующей о наличии вертикальных течений в мантии.

Что касается более глубоких горизонтов мантии, то интересной особенностью является высокоскоростная аномалия под Чукоткой на глубинах 500700 км [Bijwaard et al., 1998, Jakovlev et al., 2012, Schaeffer, Lebedev, 2013], вероятно являющаяся проявлением реликтовой зоны субдукции, проходив- 
шей здесь около 100 млн лет назад [Lobkovsky et al., 2010; Miller et al., 2010].

\section{6. ЗАКЛЮЧЕНИЕ}

Результаты изучения пространственного размещения современных сейсмических поясов на территории северо-востока Азии указывают на существование на окраинах сближающихся Евразийской и Североамериканской литосферных плит самостоятельных малых литосферных и коровых плит, ограниченных системами активных разломов. На территории северо-восточного сектора Российской Арктики главными тектоническими таксонами являются: Беринговоморская и Охотоморская малые литосферные плиты, а также Сибирская, Восточно-Сибирская и Колымо-Чукотская коровые плиты (см. рис. 1).

Анализ структурно-тектонического положения активных сегментов, систем активных разломов, параметров глубинного строения и сейсмотектонических деформаций, а также данных GPS-измерений позволил определить направления главных осей деформаций напряженно-деформированного состояния земной коры и выявить закономерность смены тектонических режимов в пределах структурного ограничения Колымо-Чукотской коровой плиты (рис. 13), а именно:

- спрединг хребта Гаккеля, который отождествляется с линейной границей между Североамериканской и Евразийской литосферными плитами. Здесь доминирует сейсмотектонический режим растяжения, где главные оси напряжений располагаются субширотно, вкрест простирания основных структурных элементов;

- рифтогенез на шельфе моря Лаптевых, для которого по параметрам сейсмотектонических деформаций установлен режим поперечного субгоризонтального растяжения. На западной и восточной границах Лаптевоморской микроплиты фиксируется режим сжатия как реакция на рифтинг, действующий в пределах шельфа моря Лаптевых;

- смешанное поле тектонических напряжений (растяжение, сжатие и их различные комбинации) в Хараулахском сегменте, где сочленяются срединно-океанические и континентальные структуры. По данным СТД здесь установлены две области с переходным типом деформационных режимов (от вертикального режима к сжатию и растяжению);
- транспрессия с левым сдвигом, фиксируемая в сейсмотектонической зоне Черского. Современные сейсмотектонические процессы происходят здесь в обстановке сжатия при моделирующем влиянии индентора жесткого массива Колымо-Омолонского супертеррейна, находящегося во фронтальной части Североамериканской плиты. Охотоморская коровая плита под воздействием сжимающих усилий выталкивается к юго-востоку, способствуя конвергенции Североамериканской и Евразийской плит;

- транспрессия с правым сдвигом, наблюдаемая на участке от Командорских до Алеутских островов по южному ограничению Беринговоморской малой литосферной плиты. Данный режим возник под влиянием северо-западного сжатия и большей скорости движения Тихоокеанской плиты;

- транспрессия в Корякском сегменте, где плиты сближаются под воздействием фронтальных сжимающих напряжений и формируют систему взбросов, надвигов и правых сдвигов, что подтверждается режимами сейсмотектонических деформаций, основной из которых характеризуется юго-восточным сжатием;

- растяжение в Чукотском сегменте, возникшее под воздействием сжатия, вызванного движением Тихоокеанской плиты к северо-западу. Рифт представляет собой зону растяжения, которая возникла между окончаниями двух крупных систем взбросов и правых сдвигов (на Корякском нагорье - Чукотке) и правых сдвигов Западной Аляски.

Таким образом, установлена более сложная геодинамическая обстановка зон взаимодействия трех главных литосферных плит - Североамериканской, Тихоокеанской и Евразийской, а также шести коровых плит (Сибирской, Амурской, Охотоморской, Лаптевоморской, Колымо-Чукотской и ВосточноСибирской), где основные деформации связаны с процессами, происходящими на границе кора мантия.

\section{7. БЛАГОДАРНОСТИ}

Исследования проведены при поддержке РНФ (проект № 15-17-20000, «Сейсмогеодинамический анализ и сейсмическое районирование восточного сегмента прибрежно-шельфовой области Российской Арктики»).

\section{8. ЛИТЕРАTУРA / REFERENCES}

Akinin V.V., Apt Yu.E., 1994. Enmelen Volcanoes (Chukotka Peninsula): Petrology of Alkaline Lavas and Deep Inclusions. SVKNII, Magadan, 97 p. (in Russian) [Акинин B.B., Anm Ю.Е. Энмеленские вулканы (Чукотский полуостров): петрология щелочных лав и глубинные включения. Магадан: СВКНИИ, 1994. 97 с.]. 
Aksenov A.A., Dunaev N.N., Ionin A.S., Kalinenko V.V., Medvedev V.S., Pavlidis Yu.A., Yurkevich M.G., 1987. Arctic Shelf of Eurasia in Late Quaternary. Nauka, Moscow, 275 p. (in Russian) [Аксенов А.А., Дунаев Н.Н., Ионин А.С., Калиненко В.В., Медведев В.С., Павлидис Ю.А., Юркевич М.Г. Арктический шельф Евразии в позднечетвертичное время. М.: Наука, 1987. 275 с.].

Angelier J., 1979. Determination of mean principal directions of stresses for a given fault population. Tectonophysics 56 (3-4), T17-T26. https://doi.org/10.1016/0040-1951(79)90081-7.

Anokhin V.M., Gusev E.A., Rekant P.V., 2003. Character of the synoceanic tectonics of the Laptev Sea oceanic margin. In: Tectonics and geodynamics of continental lithosphere. Materials of the Meeting. GEOS, Moscow, Vol. 1, p. 10-12 (in Russian) [Анохин B.M., Гусев E.A., Рекант П.В. Характер синокеанической тектоники Лаптевоморской океанической окраины // Тектоника и геодинамика континентальной литосферы: Материалы совещания. M.: ГEOC, 2003. T. 1. C. 10-12].

Apel E.V., Burgmann R., Steblov G., Vasilenko N., King R., Prytkov A., 2006. Independent active microplate tectonics of northeast Asia from GPS velocities and block modeling. Geophysical Research Letters 33 (11), L11303. https:// doi.org/10.1029/2006GL026077.

Artyushkov E.V., 2010. Continental crust in the Lomonosov ridge, Mendeleev ridge, and the Makarov basin. The formation of deep-water basins in the Neogene. Russian Geology and Geophysics 51 (11), 1179-1191. https://doi.org/ 10.1016/j.rgg.2010.10.003.

Avetisov G.P., 1996. Seismically Active Zones of the Arctic. Scientific Research Institute of Oceanology (VNIIokeanologii), St. Petersburg, 185 p. (in Russian) [Аветисов Г.П. Сейсмоактивные зоны Арктики. СПб.: ВНИИокеанологии, 1996. 185 с.].

Balakina L.M., Vvedenskaya A.V., Golubeva N.V., Misharina L.A., Shirokova E.I., 1972. The field of elastic stresses of the Earth and the Earthquake Focal Mechanism. Nauka, Moscow, 191 p. (in Russian) [Балакина Л.М., Введенская А.В., Голубева Н.В., Мишарина Л.А., Широкова Е.И. Поле упругих напряжений Земли и механизм очагов землетрясений. М.: Наука, 1972. 191 с.].

Bijwaard H., Spakman W., Engdahl E.R., 1998. Closing the gap between regional and global travel time tomography. Journal of Geophysical Research: Solid Earth 103 (B12), 30055-30078. https://doi.org/10.1029/98JB02467.

Bogdanov N.A., 2001. Continental margins: general issues of the structure and tectonic evolution. In: Yu.M. Pushcharovsky (Ed.), Fundamental problems of general tectonics. Nauchny Mir, Moscow, p. 231-249 (in Russian) [Богдaнов Н.A. Континентальные окраины: общие вопросы строения и тектонической эволюции // Фундаментальные проблемы общей тектоники / Ред. Ю.М. Пущаровский. М.: Научный мир, 2001. С. 231-249].

Cherepanova Y., Artemieva I.M., Thybo H., Chemia Z., 2013. Crustal structure of the Siberian craton and the West Siberian basin: an appraisal of existing seismic data. Tectonophysics 609, 154-183. https://doi.org/10.1016/j.tecto. 2013.05.004.

Department of Earth and Planetary Sciences at Harvard University, 2017 On-line Bulletin. Available from: http:// seismology.harvard.edu/resources (last accessed September 19, 2017).

Dong D., Herring T.A., King R.W., 1998. Estimating regional deformation from a combination of space and terrestrial geodetic data. Journal of Geodesy 72 (4), 200-214. https://doi.org/10.1007/s001900050161.

Drachev S.S., 2002. On the basement tectonics of the Laptev Sea shelf. Geotectonics 36 (6), 483-497.

Dumitru T.A., Miller E.L., O'Sullivam P.B., Amato J.M., Hannula K.A., Calvert A.T., Gans P.B., 1995. Cretaceous to recent extension in the Bering Strait region, Alaska. Tectonics 14 (3), 549-563. https://doi.org/10.1029/95TC00206.

Eittreim S., Granz A., Whitney O.T., 1979. Cenozoic sedimentation and tectonics of Hope basin, southern Chukchi Sea. In: A. Sisson (Ed.), The relationship of plate tectonics to Alaskan geology and resources. Alaska Geological Society, Anchorage, P. B-1-B-11.

Freymueller J.T., Woodard H., Cohen S.C., Cross R., Elliott J., Larsen C.F., Hreinsdóttir S., Zweck C., 2008. Active deformation processes in Alaska, based on 15 years of GPS measurements. In: J.T. Freymueller, P.J. Haeussler, R.L. Wesson, G. Ekström (Eds.), Active tectonics and seismic potential of Alaska. AGU Geophysical Monograph Series, vol. 179. P. $1-42$.

Fujita K., Koz'min B.M., 1994. Seismicity of the Amerasian Arctic shelf and its relationship to tectonic features. In: K. Thurston, K. Fujita (Eds.), Proceedings of the International Conference on Arctic Margins (1992, Anchorage, Alaska, USA). U.S. Department of the Interior, Anchorage, p. 307-312.

Fujita K., Koz'min B.M., Mackey K.G., Riegel S.A., Imaev V.S., McLean M.S., 2009. Seismotectonics of the Chersky seismic belt, Eastern Russia (Yakutia) and Magadan district, Russia. In: D.B. Stone, K. Fujita, P.W. Layer, E.L. Miller, A.V. Prokopiev, J. Toro (Eds.), Geology, geophysics and tectonics of Northeastern Russia: a tribute to Leonid Parfenov. Stephan Mueller Special Publication Series, vol. 4, p. 117-145. https://doi.org/10.5194/smsps-4-117-2009.

Fujita K., Mackey K.G., McCaleb R.C., Gunbina L.V., Kovalev V.N., Imaev V.S., Smirnov V.N., 2002. Seismicity of Chukotka, Northeastern Russia. In: E.L. Miller, A. Grantz, S.L. Klemperer (Eds.), Tectonic evolution of the Bering shelf Chukchi Sea - Artic margin and adjacent landmasses. Geological Society of America Special Papers, vol. 360, p. 259-272. https://dx.doi.org/10.1130/0-8137-2360-4.259.

Geological Map of Mountain Taimyr, 1986. Scale 1:1500000. Explanatory Note. PGO Krasnoyarskgeologia, Krasnoyarsk, 177 p. (in Russian) [Геологическая карта Горного Таймыра. Масштаб 1:1500000. Объяснительная записка. Красноярск: ПГО «Красноярскгеология», 1986. 177 с.]. 
Gephart J.W., Forsyth D.W., 1984. An improved method of determining the regional stress tensor using earthquake focal mechanism data: Application to the San Fernando earthquake sequence. Journal of Geophysical Research: Solid Earth 89 (B11), 9305-9320. https://doi.org/10.1029/JB089iB11p09305.

Global Centroid Moment Tensor Project, 2017. On-line Bulletin. Available from: http://www.globalcmt.org (last accessed September 11, 2017).

Grachev A.F., 1982. Geodynamics of transitional zone from the Moma rift to the Gakkel ridge. In: J.S. Watkins, C.L. Drake (Eds.), Continental margin Geology. American Association of Petroleum Geologists Memoirs, vol. 33, p. 103-113.

Grachev A.F., Demenitskaya R.M., Karasik A.M., 1973. The problem of a relationship between the Moma continental rift and the structure of the mid-oceanic Gakkel ridge. In: Geophysical Surveys in the Arctic. Vol. 8. NIIGA, Leningrad, p. 56-75 (in Russian) [Грачев А.Ф., Деменицкая Р.М., Карасик А.М. Проблемы связи Момского континентального рифта со структурой срединно-океанического хребта Гаккеля // Геофизические методы разведки в Арктике. Вып. 8. Л.: НИИГА, 1973. С. 56-75.

Gusev G.S., 1979. Fold Structures and Faults in the Verkhoyansk-Kolyma System of Mesozoides. Nauka, Moscow. 207 p. (in Russian) [Гусев Г.С. Складчатые структуры и разломы Верхояно-Колымской системы мезозоид. М.: Наука, 1979. 207 с.].

Gusev G.S., Mezhelovsky N.V., Imaeva L.P., 2016. Tectonic (geodynamic) processes and settings. Chapter 3. In: N.V. Mezhelovsky (Ed.), Tectonic Code of Russia. GEOKART, GEOS, Moscow, p. 59-78 (in Russian) [Гусев Г.С., Межеловский Н.В., Имаева Л.П. Тектонические (геодинамические) процессы и обстановки. Глава 3 // Тектонический кодекс России / Ред. Н.В. Межеловский. М.: ГЕОКАРТ, ГЕОС, 2016. С. 59-78].

Gushchenko O.I., 1979. The method of kinematic analysis of destruction structures in reconstruction of tectonic stress fields. In: A.S. Grigoriev, D.N. Osokina (Eds.), Fields of stress and strain in the lithosphere. Nauka, Moscow, p. 7-25 (in Russian) [Гущенко О.И. Метод кинематического анализа структур разрушения при реконструкции полей тектонических напряжений // Поля напряжений и деформаций в литосфере / Ред. А.С. Григорьев, Д.Н. Осокина. М.: Наука, 1979. С. 7-25].

Hackl M., Malservisi R., Wdowinski S., 2009. Strain rate patterns from dense GPS networks. Natural Hazards and Earth System Sciences 9 (4), 1177-1187. https://doi.org/10.5194/nhess-9-1177-2009.

Heidbach O., Tingay M., Barth A., Reinecker J., Kurfeß D., Müller B., 2010. Global crustal stress pattern based on the World Stress Map data base release 2008. Tectonophysics 482 (1-4), 3-15. https://doi.org/10.1016/j.tecto.2009. 07.023.

Imaev V.S., Imaeva L.P., Koz'min B.M., 2000. Seismotectonics of Yakutia. GEOS, Moscow, 227 p. (in Russian) [Имаев B.C., Имаева Л.П., Козьмин Б.М. Сейсмотектоника Якутии. М.: ГЕОС, 2000. 227 с.].

Imaeva L.P., Imaev V.S., Gusev G.S., Smekalin O.P., Kolodeznikov I.I., Grib N.N., Koz'min B.M., 2015a. Seismotectonics map of East Siberia: new principles and methods of mapping. Vestnik ONZ RAN (Bulletin of Earth Sciences Section RAS) 7, 1-7 (in Russian) [Имаева Л.П., Имаев В.С., Гусев Г.С., Смекалин О.П., Колодезников И.И., Гриб Н.Н., Козьмин Б.М. Карта сейсмотектоники Восточной Сибири: новые принципы и методы построения // Вестник ОНЗ PAH. 2015. T. 7. C. 1-7]. https://doi.org/10.2205/2015NZ000125.

Imaeva L.P., Imaev V.S., Koz'min B.M., 2016a. Dynamics of seismogenerating structures in the frontal zone of the Kolyma-Omolon superterrane. Geotectonics 50 (4), 349-365. https://doi.org/10.1134/S001685211604004X.

Imaeva L.P., Imaev V.S., Koz'min B.M., 2016b. Structural-dynamic model of the Chersky seismotectonic zone (continental part of the Arctic-Asian seismic belt). Journal of Asian Earth Sciences 116, 59-68. https://doi.org/10.1016/ j.jseaes.2015.11.010.

Imaeva L.P., Imaev V.S., Mel'nikova V.I., Koz'min B.M., 2016c. Recent structures and tectonic regimes of the stress-strain state of the Earth's crust in the northeastern sector of the Russian Arctic region. Geotectonics 50 (6), 535-552. https://doi.org/10.1134/S0016852116060030.

Imaeva L.P., Kozmin B.M., Imaev V.S., 2009. Seismotectonics of the northeastern Chersky zone. Otechestvennaya Geologiya (Russian Geology) (5), 56-62 (in Russian) [Имаева Л.П., Козьмин Б.М., Имаев В.С. Сейсмотектоника северо-восточного сегмента зоны Черского // Отечественная геология. 2009. № 5. С. 56-62].

Imaeva L.P., Kozmin B.M., Imaev V.S., 2011. Dynamics of focal zones of strong earthquakes in the northeastern flank of the Momo-Selennyakh depressions. Otechestvennaya Geologiya (Russian Geology) (5), 113-119 (in Russian) [Имаева Л.П., Козьмин Б.М., Имаев В.С. Динамика очаговых зон сильных землетрясений северо-восточного фланга Момо-Селенняхских впадин // Отечественная геология. 2011. № 5. С. 113-119].

Imaeva L.P., Koz'min B.M., Imaev V.S., Mackey K.G., 2015b. Structural dynamic analysis of the epicentral zone of the IlinTas earthquake (Feb 14, 2013, Ms=6.9). Journal of Seismology 19 (2), 341-353. https://doi.org/10.1007/s10950014-9469-5.

International Seismological Centre, 2017. On-line Bulletin. Available from: http://www.isc.ac.uk (last accessed September 11, 2017).

Jakovlev A.V., Bushenkova N.A., Koulakov I.Y., Dobretsov N.L., 2012. Structure of the upper mantle in the Circum-Arctic region from regional seismic tomography. Russian Geology and Geophysics 53 (10), 963-971. https://doi.org/ 10.1016/j.rgg.2012.08.001. 
Jokat W.J., Schmidt-Aursch M.C., 2007. Geophysical characteristics of the ultraslow spreading Gakkel ridge, Arctic ocean. Geophysical Journal International 168 (3), 983-998. https://doi.org/10.1111/j.1365-246X.2006.03278.x.

Khain V.E., 1973. General Geotectonics. Nedra, Moscow, 512 p. (in Russian] [Хаин B.E. Общая геотектоника. М.: Недра, 1973. 512 с.].

Kostrov B.V., 1975. Mechanics of Tectonic Earthquake Source. Nauka, Moscow, 176 p. (in Russian) [Koстров Б.B. Механика очага тектонического землетрясения. М.: Наука, 1975. 176 с.].

Kreemer C., Blewitt G., Klein C., 2014. A geodetic plate motion and global strain rate model. Geochemistry, Geophysics, Geosystems 15 (10), 3849-3889. https://doi.org/10.1002/2014GC005407.

Lander A.V., Bukchin B.G., Kiryushin A.V., Droznin D.V., 1996. Tectonic evolution and parameters of the March 8, 1991 Khailin earthquake source in Koryakia: Does the Bering Sea plate exist? Vychislitelnaya seismologia i geodinamika (Computational Seismology and Geodynamics) 3, 80-96 (in Russian) [Ландер А.В., Букчин Б.Г., Кирюшин А.В., Дрознин Д.В. Тектоническое развитие и параметры источника Хаилинского землетрясения в Корякии 8 марта 1991 г.: существует ли Беринговоморская плита? // Вычислительная сейсмология и геодинамика. 1996. T. 3. C. 80-96].

Lander A.V., Levina V.I., Ivanova E.I., 2007. The Mw 7.6 Olyutor earthquake of 20 (21) April 2006: seismic history of the region and the preliminary results of the study of a series of aftershocks. In: V.N. Chebrov (Ed.), Olyutor earthquake of 20 (21) April 2006 in the Koryak Upland. The first results of the studies. GS RAS, Petropavlovsk-Kamchatsky, p. 14-33 (in Russian) [Ландер А.В., Левина В.И., Иванова Е.И. Олюторское землетрясение 20 (21) апреля 2006 г. $M \mathrm{w}=7.6$ : сейсмическая история региона и предварительные результаты исследования серии афтершоков // Олюторское землетрясение (20 (21) апреля 2006 г., Корякское нагорье). Первые результаты исследований / Ред. В.Н. Чебров. Петропавловск-Камчатский: ГС РАН, 2007. С. 14-33].

Laske G., Masters G., Ma Z., Pasyanos M., 2013. Update on CRUST1.0 - A 1-degree Global Model of Earth's Crust. Geophysical Research Abstracts 15, EGU2013-2658. Available from: http://meetingorganizer.copernicus.org/ EGU2013/EGU2013-2658.pdf.

Lawver L.A., Grantz A., Gahagan L.M., 2002. Plate kinematic evolution of the present Arctic region since the Ordovician. In: E.L. Miller, A. Grantz, S.L. Klemperer (Eds.), Tectonic evolution of the Bering shelf - Chukchi Sea - Artic margin and adjacent landmasses. Geological Society of America Special Papers, vol. 360, p. 333-358. https://dx.doi.org/ 10.1130/0-8137-2360-4.333.

Lebedeva-Ivanova N.N., Zamansky Y.Y., Langinen A.E., Sorokin M.Y., 2006. Seismic profiling across the Mendeleev ridge at $82^{\circ} \mathrm{N}$ : evidence of continental crust. Geophysical Journal International 165 (2), 527-544. https://doi.org/ 10.1111/j.1365-246X.2006.02859.x.

Levshin A.L., Ritzwoller M.H., Barmin M.P., Villasenor A., Padgett C.A., 2001. New constraints on the arctic crust and uppermost mantle: surface wave group velocities, Pn, and Sn. Physics of the Earth and Planetary Interiors 123 (2), 185-204. https://doi.org/10.1016/S0031-9201(00)00209-0.

Lobkovsky L.I., Garagash I.A., Kononov M.V., Verzhbitsky V.E., Kotelkin V.D., 2010. Tectonics of deforming lithospheric plates and the geodynamic evolution of the Arctic region in Meso-Cenozoic. In: Geology and geoecology of continental margins in Eurasia. Vol. 2. GEOS, Moscow, p. 8-40 (in Russian) [Лобковский Л.И., Гарагаш И.А., Кононов M.В., Вержбицкий B.E., Котелкин В.Д. Тектоника деформируемых литосферных плит и геодинамическая эволюция Арктического региона в мезокайнозое // Геология и геоэкология континентальных окраин Евразии. ВЫп. 2. М.: ГЕОС, 2010. С. 8-40].

Mackey K.G., Fujita K., Gunbina L.V., Kovalev V.N., Imaev V.S., Koz'min B.M., Imaeva L.P., 1997. Seismicity of the Bering Strait region: Evidence for a Bering block. Geology 25 (11), 979-982. https://doi.org/10.1130/0091-7613(1997) 025<0979:SOTBSR>2.3.CO;2.

Mackey K.G., Fujita K., Ruff L.J., 1998. Crustal thickness of Northeast Russia. Tectonophyics 284 (3-4), 283-297. https:// doi.org/10.1016/S0040-1951(97)00180-7.

Miller E.L., Gehrels G.E., Pease V., Sokolov S., 2010. Stratigraphy and U-Pb detrital zircon geochronology of Wrangel Island, Russia: Implications for Arctic paleogeography. AAPG Bulletin 94 (5), 665-692. https://doi.org/10.1306/ 10200909036.

Myachkin V.I., Osokina D.M., Tsvetkova N.Yu., 1982. Tectonophysical analysis of stress fields and problems of focal physics of earthquake foci. In: Models of changes in the stress-strain state of rock massifs as applied to earthquake forecasting. Kola Branch of the USSR Academy of Sciences, Apatity, p. 3-24 (in Russian) [Мячкин В.И., Осокина Д.М., Цветкова Н.Ю. Тектонофизический анализ полей напряжений и проблемы физики очага землетрясений // Модели изменения напряженно-деформированного состояния массивов пород в приложении к прогнозу землетрясений. Апатиты: Кольский филиал АН СССР, 1982. С. 3-24].

Nakamura K., Plafker G., Jacob K.H., Davies J.N., 1980. A tectonic stress trajectory map of Alaska using information from volcanoes and faults. Bulletin of the Earthquake Research Institute 55 (1), 89-100.

National Earthquake Information Center, 2017. U.S. Geological Survey. On-line Bulletin. Available from: http:// earthquake.usgs.gov/data (last accessed September 11,2017).

Nokleberg W.J., Parfenov L.M., Monger J.W.H., Norton I.O., Khanchuk A.I., Stone D.B., Scotese C.R., Scholl D.W., Fujita K., 2000. Phanerozoic tectonic evolution of the Circum-North Pacific. USGS Professional Paper 1626. 122 p. 
Parfenov L.M., 1984. Continental Margins and Island Arcs of Mesozoides in Northeast Asia. Nauka, Novosibirsk, 191 р. [Парфенов Л.М. Континентальные окраины и островные дуги мезозоид северо-востока Азии. Новосибирск: Наука, 1984. 191 с.].

Parfenov L.M., Kuzmin M.I. (Eds.), 2001. Tectonics, Geodynamics and Metallogeny of the Republic of Sakha (Yakutia). Nauka, Moscow, 571 p. (in Russian) [Тектоника, геодинамика и металлогения территории Республики Саха (Якутия) / Ред. Л.М. Парфенов, М.И. Кузьмин. М.: Наука, 2001. 571 с.].

Parfenov L.M., Oksman V.S., Prokopiev A.V., Timofeev V.F., Tretyakov F.F., Trunilina V.A., Deikunenko A.V., 2001. The collage of terranes in the Verkhoyansk-Kolyma orogenic area. In: L.M. Parfenov, M.I. Kuzmin (Eds.), Tectonics, Geodynamics and Metallogeny of the Republic of Sakha (Yakutia). Nauka, Moscow, p. 199-254 (in Russian) [Пapфенов Л.М., Оксман В.С., Прокопьев А.В., Тимофеев В.Ф., Третьяков Ф.Ф., Трунилина В.А., Дейкуненко А.В. Коллаж террейнов Верхояно-Колымской орогенной области // Тектоника, геодинамика и металлогения территории Республики Саха (Якутия) / Ред. Л.М. Парфенов, М.И. Кузьмин. М.: Наука, 2001. С. 199-254].

Pinegina T.K., 2007. Seismic deformation in the epicentral zone of the Olyutor earthquake. In: V.N. Chebrov (Ed.), Olyutor earthquake of 20 (21) April 2006 in the Koryak Upland. The first results of the studies. GS RAS, Petropavlovsk-Kamchatsky, p. 126-169 (in Russian) [Пинегина T.K. Сейсмические деформации в эпицентральной зоне Олюторского землетрясения // Олюторское землетрясение 20 (21) апреля 2006 г., Корякское нагорье). Первые результаты исследований / Ред. В.Н. Чебров. Петропавловск-Камчатский: ГС РАН, 2007. C. 126-169].

Pinegina T.K., Konstantinova T.G., 2006. Macroseismic observation of consequences from April 21, 2006 Olyutor earthquake. Bulletin of Kamchatka Regional Association Education-Science Centre. Earth Sciences (1), 169-173 (in Russian) [Пинегина T.К., Константинова Т.Г. Макросейсмическое обследование последствий Олюторского землетрясения 21 апреля 2006 года // Вестник КРАУНЦ. Науки о Земле. 2006. № 1. С. 169-173].

Rebetsky Yu.L., 2007. Tectonic Stresses and Strength of Mountain Ranges. Akademkniga, Moscow, 406 p. (in Russian) [Ребецкий Ю.Л. Тектонические напряжения и прочность горных массивов. М.: Академкнига, 2007. 406 с.].

Rebetsky Yu.L., Kuchai O.A., Sycheva N.A., Tatevossian R.E., 2012. Development of inversion methods on fault slip data stress state in orogenes of the Central Asia. Tectonophysics 581, 114-131. https://doi.org/10.1016/j.tecto.2012. 09.027 .

Riznichenko Yu.V., 1985. Problems of Seismology. Nauka, Moscow, 408 p. (in Russian) [Ризниченко Ю.В. Проблемы сейсмологии. М.: Наука, 1985. 408 с.].

Rogozhin E.A., Ovsyuchenko A.N., Marakhanov A.V., Novikov S.S., 2009. Tectonic position and geological manifestations of the 2006 Olyutor earthquake in Koryakia. Geotectonics 43 (6), 443-461. https://doi.org/10.1134/S00168521 09060016.

Rogozhin E.A., Ovsyuchenko A.N., Marakhanov A.V., Novikov S.S., Pinegina T.K., 2007. Olyutor earthquake in Koryakia on 20 (21) April 2006: the results of geological and macroseismic study of the epicentral zone. In: V.N. Chebrov (Ed.) Olyutor earthquake of 20 (21) April 2006 in the Koryak Upland. The first results of the studies. GS RAS, Petropavlovsk-Kamchatsky. P. 170-206 (in Russian) [Рогожин Е.А., Овсюченко А.Н., Мараханов А.В., Новиков С.С., Пинегина Т.К. Олюторское землетрясение в Корякии 20 (21) апреля 2006 г.: результаты геологического и макросейсмического изучения эпицентральной области // Олюторское землетрясение (20 (21) апреля 2006 г., Корякское нагорье). Первые результаты исследований / Ред. В.Н. Чебров. Петропавловск-Камчатский: ГС РАН, 2007. С. 170-206].

Savostin L.A., Karasik A.M., 1981. Recent plate tectonics of the Arctic basin and Northeastern Asia. Tectonophysics 74 (1-2), 111-145. https://doi.org/10.1016/0040-1951(81)90131-1.

Schaeffer A.J., Lebedev S., 2013. Global shear speed structure of the upper mantle and transition zone. Geophysical Journal International 194 (1), 417-449. https://doi.org/10.1093/gji/ggt095.

Seredkina A.I., Kozmin B.M., 2017. Source parameters of the Taimyr earthquake of June 9, 1990. Doklady Earth Sciences 473 (1), 342-345. https://doi.org/10.1134/S1028334X1702026X.

Shapiro N.M., Ritzwoller M.H., 2002. Monte-Carlo inversion for a global shear-velocity model of the crust and upper mantle. Geophysical Journal International 151 (1), 88-105. https://doi.org/10.1046/j.1365-246X.2002.01742.x.

Shipilov E.V., 1989. Rift graben system of the Chukchi Sea. Izvestia AN SSSR (Proceedings of the USSR Academy of Sciences, Geological Series) 10, 96-107 (in Russian) [Шипилов E.B. Рифто-грабеновая система Чукотского моря // Известия АН СССР, серия геологическая. 1989. № 10. С. 96-107].

Smith W.H.F., Wessel P., 1990. Gridding with a continuous curvature surface in tension. Geophysics 55 (3), $293-305$. https://doi.org/10.1190/1.1442837.

Steblov G.M., Kogan M.G., King R.W., Scholz C.H., Bürgmann R., Frolov D.I., 2003. Imprint of the North American plate in Siberia revealed by GPS. Geophysical Research Letters 30 (18), 1924. https://doi.org/10.1029/2003GL017805.

Stovas M.V., 1965. Young tectonic uplift in the Kara, Laptev, East Siberian and Chukchi sea coastal areas. Doklady AN SSSR 161 (1), 193-194 (in Russian) [Стовас М.B. Молодое тектоническое поднятие побережья морей Карского, Лаптевых, Восточно-Сибирского и Чукотского // Доклады АН СССР. 1965. Т. 161. № 1. С. 193-194].

Suvorov V.D., Kornilova Z.A., 1986. Thickness of the crust in the southeastern Verkhoyansk-Kolyma fold area. Tikhookeanskaya geologia (Russian Journal of Pacific Geology) (4), 32-35 (in Russian) [Суворов В.Д., Корнилова 3.А 
Мощность земной коры на юго-востоке Верхояно-Колымской складчатой области // Тихоокеанская геология. 1986. № 4. С. 32-35].

Suvorov V.D., Parasotka B.S., Chernyi S.D., 1999. Deep seismic sounding studies in Yakutia. Izvestiya, Physics of the Solid Earth 35 (7-8), 612-629.

Sycheva N.A., Bogomolov L.M., Yunga S.L., 2009. Geoinformatics in the statistical approach to the calculation of seismotectonic deformation. Geoinformatika (Geoinformatics) (1), 33-43 (in Russian) [Сычева Н.А., Богомолов Л.М., Юнга С.Л. Геоинформатика в статистическом подходе к расчетам сейсмотектонических деформаций // Геоинформатика. 2009. № 1. С. 33-43].

Toro J., Amato J. M., Natal'in B., 2003. Cretaceous deformation, Chegitun River area, Chukotka Peninsula, Russia: Implications for the tectonic evolution of the Bering Strait region. Tectonics 22 (3), 1021. https://doi.org/10.1029/ $2001 \mathrm{TC} 001333$

Yunga S.L., 1990. Methods and Results of Seismotectonic Deformation Studies. Nauka, Moscow, 191 p. (in Russian) [Юнга С.Л. Методы и результаты изучения сейсмотектонических деформаций. М.: Наука, 1990. 191 с.].

Yunga S.L., 1997. Classification of seismic moment tensors on the basis of their isometric mapping on a sphere. Transactions (Doklady) of the Russian Academy of Sciences / Earth Science Sections 352 (1), 108-110.

Zhou Y., Nolet G., Dahlen F.A., Laske G., 2006. Global upper-mantle structure from finite-frequency surface-wave tomography. Journal of Geophysical Research: Solid Earth 111 (B4), B04304. https://doi.org/10.1029/2005JB003677.

Zolotorevskaya S.B., Nikitenko Yu.P., Ufimtsev G.F., 1987. Modern vertical crustal movements in East Siberia and the Far East. In: N.A. Logatchev (Ed.), Process of relief formation in Siberia. Nauka, Novosibirsk, p. 116-121 (in Russian) [Золоторевская С.Б., Никитенко Ю.П., Уфимцев Г.Ф. Современные вертикальные движения земной коры Восточной Сибири и Дальнего Востока // Процессы формирования рельефа Сибири / Ред. Н.А. Логачев. Новосибирск: Наука, 1987. С. 116-121].

Zonenshain L.P., Kuzmin M.I., Natapov L.M., 1990. Tectonics of Lithospheric Plates of the USSR Territory. Nedra, Moscow, Book 2, 334 p. (in Russian) [Зоненшайн Л.П., Кузьмин М.И., Натапов Л.М. Тектоника литосферных плит территории СССР. М.: Недра, 1990. Кн. 2. 334 с.].

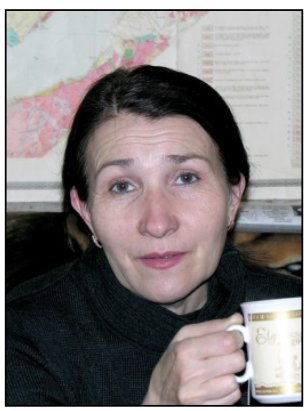

Имаева Людмила Петровна, канд. геол.-мин. наук, с.н.с

Институт земной коры СО РАН

664033, Иркутск, ул. Лермонтова, 128, Россия

Институт геологии алмаза и благородных металлов СО РАН

677007, Республика Саха (Якутия), Якутск, пр. Ленина, 39, Россия

凶e-mail: imaeva@crust.irk.ru

Imaeva, Lyudmila P., Candidate of Geology and Mineralogy, Senior Researcher Institute of the Earth's Crust, Siberian Branch of RAS

128 Lermontov street, Irkutsk 664033, Russia

Institute of Diamond and Precious Metals Geology, Siberian Branch of RAS

39 Lenin avenue, Yakutsk 677007, Sakha (Yakutia) Republic, Russia

凶 e-mail: imaeva@crust.irk.ru

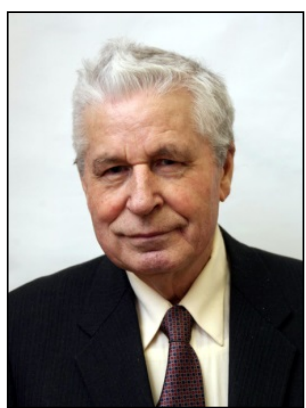

Гусев Григорий Степанович, докт. геол.-мин. наук, профессор, г.н.с.

Институт минералогии, геохимии и кристаллохимии редких элементов РАН

121357, Москва, ул. Вересаева, 15, Россия

e-mail: gusev@imgre.ru

Gusev, Grigory S., Doctor of Geology and Mineralogy, Professor, Chief Researcher Institute of Mineralogy, Geochemistry and Crystal Chemistry of Rare Elements of RAS 15 Veresaev street, Moscow 121357, Russia

e-mail: gusev@imgre.ru 

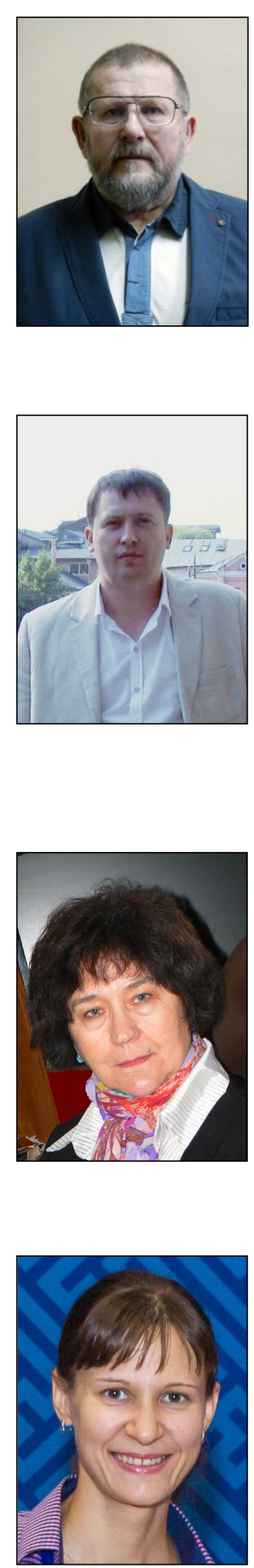

Имаев Валерий Сулейманович, докт. геол.-мин. наук, г.н.с. Институт земной коры СО РАН

664033, Иркутск, ул. Лермонтова, 128, Россия

Институт геологии алмаза и благородных металлов СО РАН

677007, Республика Саха (Якутия), Якутск, пр. Ленина, 39, Россия e-mail:imaev@crust.irk.ru

Imaev, Valery S., Doctor of Geology and Mineralogy, Chief Researcher Institute of the Earth's Crust, Siberian Branch of RAS

128 Lermontov street, Irkutsk 664033, Russia

Institute of Diamond and Precious Metals Geology, Siberian Branch of RAS

39 Lenin avenue, Yakutsk 677007, Sakha (Yakutia) Republic, Russia e-mail: imaev@crust.irk.ru

Ашурков Сергей Владимирович, канд. геол.-мин. наук, н.с.

Институт земной коры СО РАН

664033, Иркутск, ул. Лермонтова, 128, Россия

Институт геологии алмаза и благородных металлов СО РАН

677007, Республика Саха (Якутия), Якутск, пр. Ленина, 39, Россия

Тел.: (3952)429534; e-mail: ashurkov@crust.irk.ru

Ashurkov, Sergei V., Candidate of Geology and Mineralogy, Researcher Institute of the Earth's Crust, Siberian Branch of RAS

128 Lermontov street, Irkutsk 664033, Russia

Institute of Diamond and Precious Metals Geology, Siberian Branch of RAS

39 Lenin avenue, Yakutsk 677007, Sakha (Yakutia) Republic, Russia

Tel.: (3952)429534; e-mail: ashurkov@crust.irk.ru

Мельникова Валентина Ивановна, докт. геол.-мин. наук, г.н.с.

Институт земной коры СО РАН

664033, Иркутск, ул. Лермонтова, 128, Россия

Институт геологии алмаза и благородных металлов СО РАН

677007, Республика Саха (Якутия), Якутск, пр. Ленина, 39, Россия

e-mail: vimel@crust.irk.ru

Melnikova, Valentina I., Doctor of Geology and Mineralogy, Chief Researcher Institute of the Earth's Crust, Siberian Branch of RAS

128 Lermontov street, Irkutsk 664033, Russia

Institute of Diamond and Precious Metals Geology, Siberian Branch of RAS

39 Lenin avenue, Yakutsk 677007, Sakha (Yakutia) Republic, Russia

e-mail:vimel@crust.irk.ru

Середкина Алена Игоревна, канд. физ.-мат. наук, с.н.с.

Институт земной коры СО РАН

664033, Иркутск, ул. Лермонтова, 128, Россия

Институт геологии алмаза и благородных металлов СО РАН

677007, Республика Саха (Якутия), Якутск, пр. Ленина, 39, Россия

e-mail: ale@crust.irk.ru

Seredkina, Alena I., Candidate of Physics and Mathematics, Senior Researcher Institute of the Earth's Crust, Siberian Branch of RAS

128 Lermontov street, Irkutsk 664033, Russia

Institute of Diamond and Precious Metals Geology, Siberian Branch of RAS

39 Lenin avenue, Yakutsk 677007, Sakha (Yakutia) Republic, Russia e-mail: ale@crust.irk.ru 